\title{
Corporate Debt Maturity and Future Firm Performance Volatility
}

\author{
Meg Adachi-Sato \\ School of Economics, Finance, and Marketing \\ Royal Melbourne Institute of Technology University \\ Melbourne, Victoria 3000, Australia \\ Tel: +61039925 5450 \\ E-mail: meg.sato@ rmit.edu.au \\ Chaiporn Vithessonthi* \\ Sunway University Business School \\ Sunway University
}

No. 5, Jalan Universiti, Sunway City, 47500 Selangor Darul Ehsan, Malaysia

Tel: +60 374918622 Ext. 7104 Fax: +60 356358633

Email: chaipornv@sunway.edu.my

*Corresponding author 


\title{
Corporate Debt Maturity and Future Firm Performance Volatility
}

\begin{abstract}
We propose a simple idea that corporate debt maturity should serve as a good indicator of future firm performance volatility. We show in a simple two-period model that the riskiness of corporate investment is a decreasing function of corporate debt maturity. If "observable" corporate debt maturity and ex ante "unobservable" corporate risk-taking is highly correlated, corporate debt maturity should be highly correlated with "ex post" realized firm performance volatility in following years. Using data on firms in 10 developing and developed countries during 1991-2013, we find that corporate debt maturity is negatively associated with future firm operating performance volatility but is not associated with future firm value volatility.
\end{abstract}

JEL Classification: E22; F4; G1; G30; G31; G32

Keywords: Debt maturity; Firm performance volatility; Firm value volatility; Investment; Risk-taking

\section{Introduction}

One of the main tenets in finance is that an asset's expected return is a function of risk (see e.g., Fama \& French, 1993; W. Huang, Liu, Ghon Rhee, \& Wu, 2012; Tinic \& West, 1984; Watanabe \& Watanabe, 2008). That is, the expected return is an increasing function of risk. In this paper, we develop a simple two-period model and show that the riskiness of corporate investment is a decreasing function of corporate debt maturity (hereafter "debt maturity"). We relate future firm performance volatility, which is one way of "ex post" 
measuring "ex ante" unobservable corporate risk-taking, to debt maturity, which is conceivably a measure of financial risk.

Our simple two-period model is able to capture and build on empirical evidence that (1) firms tend to have shorter debt maturity in years prior to banking/financial crises (Brockman, Martin, \& Unlu, 2010; Harford, Klasa, \& Maxwell, 2014) and (2) firms appear to have higher performance volatility in recent years (e.g., Faccio, Marchica, \& Mura, 2011). Both facts are also documented in this study. When firms use debt to finance their investment, they also choose their level of short- and long-term debt. Shortening debt maturity (i.e., increasing the share of short-term debt) subjects firms to a greater level of rollover risk (Acharya, Gale, \& Yorulmazer, 2011; He \& Xiong, 2012).

In our model, a macro-level financial shock (e.g., a banking/financial crisis) can occur at the interim period. When short-term debt investors anticipate a financial shock to occur with high certainty, they withdraw from the debt markets by not rolling over firms' maturing short-term debt. Due to lack of the secondary market for long-term debt (or due to illiquidity of the secondary market for long-term debt), long-term debt investors cannot reverse their position at the interim period and thus are more exposed to a financial shock. Focusing on the discounted value of net profit of the success state of nature, we show that the investment's probability of success must equal or exceed a certain level (called "the investment threshold") so that the discounted value of net profit of the success state of nature is nonnegative. Focusing on the investment threshold, we find that the investment threshold decreases when the share of short-term debt in total debt increases. Lowering the investment threshold implies that riskier projects (e.g., projects with lower probabilities of success) become investable, allowing firms to invest in riskier projects even if financial leverage remains unaltered. 
In a nutshell, three central insights obtained from our theoretical model are as follows. First, having shorter debt maturity allows or induces firms to invest in riskier projects. The larger proportion of short-term debt in total debt not only allows firms to invest in projects with smaller probabilities of success but also exacerbates the problem of maturity mismatch. ${ }^{1}$ This insight supports the notion that when firms rely on short-term debt to finance their investment too excessively, the level of corporate risk-taking in the economy becomes substantially higher. Second, investors prefer to buy short-term debt than long-term debt since short-term debt allows holders to be largely exempt from bearing bankruptcy costs prior to the onset of a financial shock and corporate default in the interim period. The demand for short-term debt results in the higher value of short-term debt and thus the lower return on short-term debt. Third, due to lack of the secondary market for long-term debt (or the presence of illiquidity of the secondary market for long-term debt), investors require the higher return on long-term debt to compensate for bearing additional risk, relative to shortterm debt.

Building from the insights obtained from our model, we argue that "observable" debt maturity contemporaneously correlates with the level of ex ante "unobservable" corporate risk-taking in investment. If ex ante corporate risk-taking in investment highly correlates with ex post realized firm performance volatility, debt maturity should be able to explain future firm performance volatility. Our rationale for using ex post realized firm performance volatility as a measure of ex ante corporate risk-taking is primarily drawn upon the asset pricing and corporate finance literature that measures risk or risk-taking as the volatility of stock returns (e.g., Brown, Jha, \& Pacharn, 2015) or earnings (e.g., Faccio, Marchica, \& Mura, 2016; Li, Griffin, Yue, \& Zhao, 2013). For example, González-Urteaga and Rubio (2016) show that the default premium is one of key factors explaining the cross-sectional

\footnotetext{
${ }^{1}$ See e.g., Farhi and Tirole (2012) for a detailed discussion on maturity mismatch.
} 
variation of average volatility of risk premia, while Faccio, et al. (2016) examine a relation between CEO gender and corporate risk-taking, measured as the standard deviation of the firm's ROA.

We suggest that under certain conditions, debt maturity has a stronger or weaker effect on firm performance volatility. We test our predictions using a panel data set of publicly listed firms in 10 countries (i.e., six advanced economies, including Germany, Japan, South Korea, Switzerland, the United Kingdom, and the United States, and four emerging markets economies, including Brazil, Indonesia, Malaysia and Thailand) during the period 19912013.

We use (1) firm operating performance volatility (SDROA), measured as the three-year rolling standard deviation of ROA, and (2) firm value volatility (SDTBQ), measured as the three-year rolling standard deviation of Tobin's Q, to proxy for firm performance volatility. To estimate the impact of debt maturity on future firm performance volatility, we employ panel OLS regressions as well as two-stage least squares (2SLS) regressions.

We empirically show that current firm operating performance volatility, which is observed at time $t$, is negatively associated with past debt maturity, which is observed at time $t-3$, after controlling for a large set of firm characteristics, industry conditions, and macroeconomic conditions. Our findings are also robust to controlling for the unobservable time-invariant firm-specific effects, unobservable time-invariant industry-specific effects, unobservable time-invariant country-specific effects, and year effects. Regarding the economic significance, given the estimated coefficient of debt maturity of -0.008 (see column (2) of Table 4), the standard deviation of debt maturity of 33.50 and the mean of firm operating performance volatility (SDROA) of 4.83 (see Table 1), an increase of one standard deviation in debt maturity would reduce SDROA by about -0.055 or $5.5 \%(=-0.008 \times$ 
33.50/4.83) at the mean. We find that leverage is positively associated with future firm performance volatility in models that include both leverage and debt maturity.

However, we find no evidence for the effect of debt maturity on future firm value volatility, measured as the volatility of Tobin's Q. One possible interpretation of this finding that investors may not have sufficient information on a firm's investment and thus do not incorporate an investment's value into a firm's stock price, leading to no association between debt maturity and future firm value volatility. Another possible interpretation of the finding is that investors do not use debt maturity as a primary proxy for an investment's riskiness; therefore, debt maturity is not associated with future firm performance volatility. This interpretation is supported by the fact that capital investment (CAPEXTA) and leverage (LEV) have a positive effect on future firm value volatility.

The results of our paper provide new evidence that debt maturity and "unobservable" ex ante corporate risk-taking are more likely to be highly correlated, given that debt maturity is negatively associated with future firm operating performance. These findings can have implications for both firms and corporate debt holders. For instance, our findings, by quantifying the relationship between debt maturity and future firm performance volatility, are relevant for banks' loan officers considering loan applications. That is, when assets with long maturity are financed with shorter debt maturity, it is possible that firms are more likely to have higher corporate risk-taking. This finding is important because the effect of debt maturity on future operating performance remains evident even after controlling for growth options. Scholars such as Harford, et al. (2014) note that firms with higher growth options (e.g., measured as MBV) should have shorter debt maturity.

The reminder of the article proceeds as follows. Section 2 provides a brief overview of related studies, our theoretical model and testable hypotheses. Next, we present our sample 
and methodology in Section 3. We report and discuss our empirical results in Section 4. We conclude our paper in Section 5.

\section{Related literature and hypothesis development}

To build arguments for the impact of debt maturity on future firm performance volatility, we primarily draw upon related studies that examine under- and over-investment problems (see e.g., Aggarwal \& Samwick, 2006; Aivazian, Ge, \& Qiu, 2005; Bolton, Chen, \& Wang, 2011; Butler, Cornaggia, Grullon, \& Weston, 2011; Julio \& Yook, 2012; Myers, 1977; Myers \& Majluf, 1984). Our theoretical arguments are built upon prior studies related to debt maturity (see e.g., Barclay \& Smith, 1995; Diamond, 1991; Fan, Titman, \& Twite, 2012; Flannery, 1986; González \& González, 2014; Jeon \& Nishihara, 2015).

\subsection{Corporate debt structure and investment}

Flannery (1986) earlier argues that when the same information about a firm's prospect is shared between insiders (e.g., managers) and outsiders (e.g., outside investors), the composition of debt will be priced in a way that causes the firm to be indifferent to the composition. When information asymmetries exist, better-informed insiders (e.g., managers) will attempt to choose their debt structure to maximize firm value. Brick and Ravid (1985) show in a model that when a gain from leverage exists, an increasing term structure of interest rates, which is adjusted for default risk, leads to long-term debt being optimal. Under similar conditions, a decreasing term structure of interest rates results in short-term debt being optimal. As noted by Diamond (1991), firms with lower credit ratings typically prefer long-term debt while firms with higher credit ratings generally prefer short-term debt. Barclay and Smith (1995) provide supporting empirical evidence for the contracting-cost 
hypothesis. That is, large firms or firms with limited growth opportunities have more longterm debt. In addition, they show that the level of information asymmetries influences debt maturity in the sense that firms with higher levels of information asymmetries are more likely to use more short-term debt. Rauh and Sufi (2010) show that low-credit-quality firms tend to have a multi-tiered capital structure than high-credit-quality firms.

There is a growing body of research on the influence of interest rates on a firm's capital structure. For example, De Haan and Sterken (2006) examine the sensitivity of corporate debt structures to changes in monetary policy for a sample of firms in the Euro area and the UK. They find empirical support for the broad credit view where firms that are more bankdependent are more strongly affected by tightening monetary policy than firms that are less bank-dependent and have access to non-bank forms of external finance. Ju and Ou-Yang (2006) find that the long-run average interest rate plays an important role in determining a firm's optimal capital structure and debt maturity and that the volatility of interest rate is associated with debt maturity. Fan, et al. (2012) show that country-level conditions can explain a substantial portion of the variation in leverage and debt maturity in a sample of firms in 39 countries. For instance, leverage is higher for firms in more corrupt countries. In addition, firms in these countries are more likely to use more short-term debt. Firms in countries with explicit bankruptcy codes and deposit instance are more likely to use more long-term debt. Vig (2013) uses a sample of firms in India to show that tightening of creditor rights leads to liquidation bias and a reduction in total debt, a fall in secured debt, and a decrease in debt maturity.

Scholars such as Barclay and Smith (1995) and Khurana and Wang (2015) argue that short-term debt can mitigate agency costs of debt (arising from information asymmetry and suboptimal investment problems) by constraining managerial risk-taking. Studies related to the influence of executive compensation show that executive compensation affects 
managerial risk preferences. For example, Datta, Iskandar-Datta, and Raman (2005) show that managerial stock ownership significantly explains variation in debt maturity after controlling for factors that have been previously shown to determine debt maturity. More precisely, managerial stock ownership negatively affects debt maturity and exerts an influence on a relationship between growth opportunities and debt maturity. Brockman, et al. (2010) argue that large deltas (i.e. executives' portfolio sensitivities to changes in stock prices) negatively affect managerial risk-taking, whereas large vegas (i.e. executives' portfolio sensitivities to changes in stock return volatility) positively affect managerial risktaking. They find that debt maturity positively correlates with CEO portfolio deltas and negatively correlates with CEO portfolio vegas.

Prior studies (e.g., Aivazian, et al., 2005; Bolton, et al., 2011; Dell'Ariccia \& Marquez, 2010) show that debt maturity has a significant effect on corporate investment decisions. For instance, Aivazian, et al. (2005) find that debt maturity negatively affects investment for firm with high growth opportunities after controlling for the level of leverage but this effect is insignificant for firms with low growth opportunities. In a recent study, D’Mello and Miranda (2010) show that for unlevered firms, a fall in overinvestment is due to debt service obligations following the issuance of long-term debt. In another closely related study, Jeon and Nishihara (2015) propose a model that illustrates an impact of debt maturity on corporate investment.

\subsection{A two-period model}

In this section, we show within a simple two-period model an impact of debt maturity on corporate risk-taking. To simplify our exposition, we consider a simple model of an economy with firms with limited liability and investors at three time instances, $t=0,1$, and 2 . In our model, investors refer to those who are interested in holding fixed-income assets such as 
short- and long-term bonds (or short- and long-term loans with fixed interest rates); hence, investors can be, for example, commercial banks, insurance companies, and households.

Suppose that firms have an investment opportunity at $t=0$. Firms have their own fund or so-called equity (denoted by $\bar{K}$ ) but need to borrow an additional fund $B(\geq 0)$ from investors at $t=0$ to take up their investment opportunity, equaling the amount $I=\bar{K}+B$. The ratio of $B /(\bar{K}+B)$ is viewed as financial leverage. If this investment opportunity is taken up at time $t$ $=0$, it becomes an investment $(I)$ that has a liquidation value (denoted by $V$ ) at $t=1$, generates no cash flows at $t=1$ and provides a payoff (e.g., cash flows) at $t=2$. We assume that the liquidation value at $t=1$ is positive because the investment asset still has some productive value if it is used for another purpose at $t=1$. However, we also assume that the liquidation value at $t=2$ is zero because the investment asset cannot be used for another purpose at $t=2$.

Between $t=1$ and $t=2$, an economy-wide financial shock occurs with probability $1-\omega$. If a financial shock does not occur, the investment $(I)$ yields $R(I) \equiv R(\bar{K}+B)>0$ per investment amount (or 0 per investment amount) with probability $\theta \in[0,1]$ (or with probability $(1-\theta))$ at $t=2$, where $R^{\prime}(\bar{K}+B)>0$ and $R^{\prime \prime}(\bar{K}+B)<0 .{ }^{2}$ At $t=0$, both firms and investors know that the success probability of obtaining $R(\bar{K}+B)$ is drawn from the prior

\footnotetext{
${ }^{2}$ Note that we assume the presence of symmetric information in the model. As a result, the probability $\theta$ is different for each firm but is publicly known or the probability $\theta$ is identical to any firm. However, in our model, the investment decision is made before the probability $\theta$ is realized. Hence, whether or not $\theta$ is firm-specific does not affect the equilibrium of the model. In this sense, it is not crucial for our analysis to formally distinguish between the firmspecific $\theta_{i}$ and the industry-specific $\theta$. For simplicity, we use $\theta$ in both of these cases in the subsequent analysis.
} 
distribution $G(\theta)$. By contrast, if a financial shock occurs at $t=1$, the investment yields neither cash flows nor liquidation value (i.e. both cash flows and liquidation value are zero) at $t=2$. At $t=1$, every agent knows whether a financial shock occurs between $t=1$ and $t=2$.

We assume that at $t=0$ the firms use short-term (one-period) debt (e.g., short-term bonds) to finance the ratio $\alpha$ of $B$ (i.e., the amount $\alpha B$ ) and use long-term (two-period) debt (e.g., long-term bonds) to finance the remaining ratio $1-\alpha$ of $B$ (i.e., the amount $(1-\alpha) B){ }^{3}$ The face value (i.e. the par value) of the short-term debt maturing at $t=1 \mathrm{is} S_{1}$; the face value of the short-term debt maturing at $t=2$ is $S_{2}$; the face value of long-term debt maturing at $t=$ 2 is $L$.

To make our analysis meaningful, we add the following assumption.

Assumption 1: $[1-\alpha+\alpha(1-\omega) \kappa]\left[R^{\prime-1}\left(\frac{(1+r)^{2}}{\omega E(\theta)}[1-\alpha(1-\omega)(1-\kappa)]\right)-\bar{K}\right]>\frac{(1-\omega) \kappa V}{1+r}$.

Here, $\kappa$ denotes the share of a long-term bondholder's claim to the firm's investment in a financial shock, which will be discussed in more detail later. Assumption 1 ensures that the long-term debt is positive. This assumption can be justified if neither $V$ nor $\bar{K}$ are sufficiently large. To simplify the analysis, we also assume that

Assumption 1A: $\quad S_{1}<V<S_{1}+L$,

Assumption 1B: $\quad S_{2}+L<R(\bar{K})$,

\footnotetext{
${ }^{3}$ In practice, there is an upper bound of the ratio $\alpha$, which is determined by outside investors. For example, firms cannot finance the full amount of $B$ by issuing only short-term debt.
} 
Assumption 1C: $\quad V<R(\bar{K}) /(1+r) .^{4}$

Here, $r$ denotes the discount rate in each period and is assumed to be the risk-free interest rate because all of our agents in the model are risk-neutral. Consistent with prior studies such as Bolton, Chen, and Wang (2013) and Diamond and He (2014), we assume that the discount rate $r$ is exogenous and constant in each period. ${ }^{5}$ The first inequality (of Assumption 1A) implies that the liquidation value $V$ can cover the claims of short-term debt holders at $t=1$

${ }^{4}$ Using the exogenous parameters, it follows from Equations (4)--(6) that these assumptions are equivalent to imposing the following inequalities:

$$
\begin{aligned}
& (1+r) \alpha\left[R^{\prime-1}\left(\frac{(1+r)^{2}}{\omega E(\theta)}[1-\alpha(1-\omega)(1-\kappa)]\right)-\bar{K}\right]<V ; \\
& V<\left[1+\frac{(1+r)(1-\omega) \kappa}{\omega E(\theta)}\right]^{-1}\left\{(1+r) \alpha+\frac{(1+r)^{2}}{\omega E(\theta)}[1-\alpha+\alpha(1-\omega) \kappa]\right\} \\
& \quad\left[R^{\prime-1}\left(\frac{(1+r)^{2}}{\omega E(\theta)}[1-\alpha(1-\omega)(1-\kappa)]\right)-\bar{K}\right] ; \\
& \frac{(1+r)^{2}}{E(\theta)}\left\{\left[\alpha+\frac{1-\alpha+\alpha(1-\omega) \kappa}{\omega}\right]\left[R^{\prime-1}\left(\frac{(1+r)^{2}}{\omega E(\theta)}[1-\alpha(1-\omega)(1-\kappa)]\right)-\bar{K}\right]-\frac{(1-\omega) \kappa V}{\omega(1+r)}\right\}<R(\bar{K}) ;
\end{aligned}
$$
and $V<R(\bar{K}) /(1+r)$. The final two inequalities are satisfied if $R$ is sufficiently large for any $B \geq \bar{K}$.

${ }^{5}$ Several related studies assume that the interest rate is exogenous, and/or the discount rate is the risk free rate of return. For example, Bolton, et al. (2013) assume that the discount rate is the risk-free interest rate. Dell'Ariccia and Marquez (2010) assume that the average market interest rate is fixed, whereas Rampini and Viswanathan (2010) assume that the price of capital is exogenous. Greenwood, Hanson, and Stein (2010) assume that short-term interest rates are exogenous and examine the impact of debt maturity of government on corporate debt maturity. 
but cannot compensate for the sum of the claims of short-term debt $\left(S_{1}\right)$ and long-term debt (L) at $t=1$. The inequality in Assumption 1B guarantees that cash flows generated by the firm's investment in case of having an investment success in the absence of the financial crisis can cover the sum of the claims of short-term $\left(S_{2}\right)$ and long-term debt $(L)$ at $t=2$. The inequality in Assumption 1C ensures that the firm does not default on its debt voluntarily.

If the investors provide short-term financing to the firm by buying the firm's short-term bonds, they are willing to roll over short-term bonds at $t=1$ in the absence of the financial shock occurring at time $t=1$; however, the short-term investors receive $S_{1}$ and no longer provide new short-term financing to the firm in the presence of the financial shock at $t=1 .^{6}$ The time- 0 expected discounted payoff of the short-term bond is then

$$
-\alpha B+\frac{1}{1+r}\left[\omega\left(S_{1}-S_{1}\right)+(1-\omega) S_{1}\right]+\frac{1}{(1+r)^{2}} \omega E[\theta] S_{2},
$$

where $E$ is the expectation operator. Recall that $S_{1}<V, S_{2}+L<R(\bar{K}), B \geq 0$, and $R^{\prime}(\bar{K}+B)>0$

If the investors provide long-term financing to the firm by buying the firm's longterm bonds, in the absence of a financial shock, they receive nothing at $t=1$, obtain $L$ at $t=2$ when the firm's investment succeeds, and obtain 0 at $t=2$ when the firm's investment fails. In a financial shock state of nature, the long-term investors receive the residual claim

\footnotetext{
${ }^{6}$ Put it differently, at $t=1$, in a non-financial crisis state, firms can roll over their short-term debt by issuing new short-term debt to replace matured short-term debt. If a financial shock occurs at $t=1$, firms cannot roll over their short-term debt since investors do not buy their short-term debt.
} 
$\kappa\left(V-S_{1}\right)$ at $t=1$ but do not obtain anything at $t=2$, where $1-\kappa \in(0,1)$ is the bankruptcy cost. This is because we assume that the firm is in default at $t=1$ if a financial shock is predicted to occur between $t=1$ and $t=2$ with high certainty and the short-term investors no longer buy new short-term bonds at $t=1$. In our model, the short-term debt has the priority over the long-term debt because the short-term debt investors can withdraw their funds at $t=$ 1 prior to the firm's default, and that $S_{1}<V<S_{1}+L, S_{2}+L<R(\bar{K}), B \geq 0$, and $R^{\prime}(\bar{K}+B)>0$. Thus, the time-0 expected discounted payoff of the long-term bond for the investors is

$$
-(1-\alpha) B+\frac{1}{1+r}(1-\omega) \kappa\left(V-S_{1}\right)+\frac{1}{(1+r)^{2}} \omega E[\theta] L
$$

We assume that at $t=0$ the investors invest in bonds as long as the expected discounted payoff is larger than or equal to zero (i.e., non-negative). Hence, in the competitive bond market at $t=0$, we must have

$$
\frac{1}{1+r}\left[\omega\left(S_{1}-S_{1}\right)+(1-\omega) S_{1}\right]+\frac{1}{(1+r)^{2}} \omega E[\theta] S_{2}=\alpha B
$$

and

$$
\frac{1}{1+r}(1-\omega) \kappa\left(V-S_{1}\right)+\frac{1}{(1+r)^{2}} \omega E[\theta] L=(1-\alpha) B
$$

In addition, when the investors agree to roll over the firm's short-term debt at $t=1$ in the absence of a financial shock, their expected discounted payoff to the investors who roll over 
the firm's short-term debt at $t=1$ must be larger than or equal to zero. Hence, the following condition must be satisfied in the competitive bond market at $t=1$ :

$$
\frac{1}{1+r} E[\theta] S_{2}=S_{1}
$$

Equations (3)--(5) can characterize the equilibrium conditions of the firm's short-term and long-term bonds and endogenously determine the short-term interest rates $\frac{S_{1}}{\alpha B}-1$ at $t=0$ and $\frac{S_{2}}{S_{1}}-1$ at $t=1$, and the long-term interest rate $\frac{L}{(1-\alpha) B}-1$ at $t=0$.

We now proceed to determine $S_{1}, S_{2}$, and $L$ simultaneously by equations (3)--(5) relative to the size of a given external fund $B$. Then, it is straightforward from (3)--(5) that we have

$$
\begin{aligned}
& S_{1}(B)=(1+r) \alpha B \\
& S_{2}(B)=\frac{(1+r)^{2}}{E(\theta)} \alpha B, \\
& L(B)=\frac{(1+r)^{2}}{\omega E(\theta)}\left\{[1-\alpha+\alpha(1-\omega) \kappa] B-\frac{(1-\omega) \kappa V}{(1+r)}\right\} .
\end{aligned}
$$

As we will show that the equilibrium investment level, implied by the equilibrium debt level, is given by Equation (11) if the firm takes up the investment opportunity, it follows from Assumption 1 and $\theta \in[0,1]$ that $\left(S_{1}, S_{2}, L\right) \geq 0$ and $S_{1}<S_{2}$ in the bond market equilibrium.

Because of Assumptions 1A and 2B that $S_{1}<V<S_{1}+L$ and $S_{2}+L<R(\bar{K})$, the present discounted value of the expected net profit $\pi$ of the investment with success probability $\theta$ conditional on the event of no financial shock is represented by 


$$
\pi=\frac{\omega E(\theta)\left[R(B+\bar{K})-S_{2}(B)-L(B)\right]}{(1+r)^{2}}-\bar{K} .
$$

Thus, if the firm undetakes the investment, its objective is to maximize the present discounted value of the expected net profit $\pi$ of Equation (9) with respect to the amount of total debt $B$. Using (7) and (8), the first-order condition is then written by

$$
\frac{\omega E(\theta)}{(1+r)^{2}} R^{\prime-1}(B+\bar{K})-1+\alpha(1-\omega)(1-\kappa)=0
$$

Solving (10), we obtain the equilibrium debt amount $B^{*}$ expressed by

$$
B^{*}=R^{\prime-1}\left(\frac{(1+r)^{2}}{\omega E(\theta)}[1-\alpha(1-\omega)(1-\kappa)]\right)-\bar{K}
$$

However, the present discounted value of the expected net profit $\pi$ in Equation (9) must be non-negative to compensate the equity holders for bearing risk if the firm undertakes the investment. Indeed, it follows from (9) and (11) that the present discounted value of the expected net profit of the firm with the expected success probability $E(\theta)$ conditional on the event of no financial shock is nonnegative only if $E(\theta) \geq \bar{\theta}\left(B^{*}\right)$, where

$$
\bar{\theta}\left(B^{*}\right) \equiv \frac{(1+r)^{2} \bar{K}}{\omega\left[R\left(B^{*}+\bar{K}\right)-S_{2}\left(B^{*}\right)-L\left(B^{*}\right)\right]}>0
$$


Note that $S_{2}\left(B^{*}\right)$ and $L\left(B^{*}\right)$ are obtained by evaluating $S_{2}$ and $L$ given by (7) and (8) at $B=$ $B^{*}$ from (11). The final inequality in (12) is evident from the assumptions that $S_{2}+L<R(\bar{K})$, $B \geq 0$, and $R^{\prime}(B+\bar{K})>0$. Thus, firms with the project with the expected success probability conditional on the event of no financial shock, $E(\theta) \geq \bar{\theta}\left(B^{*}\right)$, borrow additional funds from outsiders and invest in the project. In addition, firms should not invest in any project with the expected success probability conditional on the event of no financial shock $E(\theta)<\bar{\theta}\left(B^{*}\right) .^{7}$

Substituting (7), (8), and (11) into (12), we characterize the investment threshold $\bar{\theta}$ more specifically as follows:

$$
\bar{\theta}\left(B^{*}\right) \equiv \frac{(1+r)^{2} \bar{K}}{\omega\left\{R\left(B^{*}+\bar{K}\right)-\frac{(1+r)^{2}}{E(\theta)}\left[\alpha+\frac{1-\alpha+\alpha(1-\omega) \kappa}{\omega}\right] B^{*}+\frac{(1+r)(1-\omega) \kappa V}{\omega E(\theta)}\right\}}>0
$$

where the optimal debt level $B^{*}$ is given by (11). Differentiating $B^{*}$ and $\bar{\theta}\left(B^{*}\right)$ with respect to $\alpha$ and using (10) and $R^{\prime \prime}<0$, we obtain

$$
\frac{d B^{*}}{d \alpha}=-\frac{1}{R^{\prime \prime}\left(B^{*}+\bar{K}\right)} \frac{(1+r)^{2}}{\omega E(\theta)}(1-\omega)(1-\kappa)>0,
$$

\footnotetext{
${ }^{7}$ The threshold condition $E(\theta) \geq \bar{\theta}\left(B^{*}\right)$ is viewed as a minimum condition for a possible positive NPV project since, from the shareholders' perspective, Equation (9) describes the payoff of the investment. Hence, for the investment to have the time-0 positive expected net present value of the project, a necessary condition is that $\frac{\omega E(\theta)\left[R\left(B^{*}+\bar{K}\right)-S_{2}\left(B^{*}\right)-L\left(B^{*}\right)\right]}{(1+r)^{2}}-\bar{K}>0$.
} 


$$
\frac{d \bar{\theta}}{d \alpha}=\frac{(1+r)^{2} \bar{K}}{\omega} \frac{1}{\left[R\left(B^{*}+\bar{K}\right)-S_{2}\left(B^{*}\right)-L\left(B^{*}\right)\right]^{2}}\left\{-R^{\prime}\left(B^{*}+\bar{K}\right) \frac{d B^{*}}{d \alpha}+\frac{d\left[S_{2}\left(B^{*}\right)+L\left(B^{*}\right)\right]}{d \alpha}\right\}
$$

where

$$
\begin{aligned}
& R^{\prime}\left(B^{*}+\bar{K}\right) \frac{d B^{*}}{d \alpha}-\frac{d\left[S_{2}\left(B^{*}\right)+L\left(B^{*}\right)\right]}{d \alpha} \\
& =\left\{R^{\prime-1}\left(B^{*}+\bar{K}\right)-\frac{(1+r)^{2}[1-\alpha(1-\omega)(1-\kappa)]}{\omega E(\theta)}\right\} \frac{d B^{*}}{d \alpha}+\frac{(1+r)^{2}}{E(\theta)} \frac{(1-\omega)(1-\kappa)}{\omega} B^{*} \\
& =\frac{(1+r)^{2}}{E(\theta)} \frac{(1-\omega)(1-\kappa)}{\omega} B^{*}>0 .
\end{aligned}
$$

Thus, it follows from (14)--(16) that

$$
\frac{d B^{*}}{d \alpha}>0 \text { and } \frac{d \bar{\theta}}{d \alpha}<0
$$

The first inequality of (17) shows that shortening debt maturity (a larger value of $\alpha$; i.e., increasing the ratio of short-term debt to total debt) increases the investment level $I=B^{*}+\bar{K}$ via the increase in the debt amount $B *$ if the firm takes up the investment opportunity. The second inequality of (17) indicates that shortening debt maturity lowers a success investment threshold (i.e., a smaller value of $\bar{\theta}$ ). Because a lower investment threshold implies that the firm invests in riskier projects (e.g., projects with lower probabilities of yielding $R$ ), this result shows that the riskiness of corporate investment is decreasing in the length of debt maturity. 
The intuition behind (17) is that the short-term debt investors can withdraw their funds before the event of firm default, whereas the long-term debt investors cannot. ${ }^{8}$ This implies that the short-term debt investors can recover their investment funds even though the future prospect of the project of the firm deteriorates. Hence, if the short-term debt has the priority over the long-term debt, firms are more likely to invest in riskier projects (in terms of the amount of the investment and the quality of the investment). ${ }^{9}$

It also follows from Equations (14) and (15) that a relationship between debt maturity and the riskiness of corporate investment is non-linear. Overall, we suggest the following proposition:

Proposition 1: Corporate investment is riskier if debt maturity is shorter. That is, the riskiness of corporate investment is a decreasing function of debt maturity. Furthermore, the relationship between debt maturity and the riskiness of corporate investment is non-linear.

\footnotetext{
${ }^{8}$ We assume for simplicity that there is no secondary market for long-term bonds; therefore, all long-term bond investors cannot sell their long-term bonds at $t=1$. If this assumption is relaxed, our main conclusion remains largely unaltered.

${ }^{9}$ This outcome is consistent with the view that under normal circumstances, investors require additional compensation for holding long-term bonds, leading to higher interest rates on longterm bonds, compared to short-term bonds. Hence, high credit-quality firms that have access to short-term bond markets prefer to issue short-term bonds to finance their (long-term) investment. In this sense, the insights from our model are reminiscent of those suggested by Farhi and Tirole (2012) in the case of debt maturity for banks.
} 
Our theoretical model deserves some comments on its implications. While it is a representation of a corporate debt maturity choice, it has some economy-wide consequences. We discuss two primary implications in more detail below.

Implication 1: In the cross-section of firms with risky investment, a high proportion of shortterm debt to total debt exposes firms to a greater level of rollover risk.

Implication 1 is a by-product consequence of the model's assumption that the short-term debt investors can withdraw funds at the interim period (i.e., at $t=1$ in our model). In anticipation of a financial shock, the short-term debt investors are unlikely to rollover the firms' short-term debt, causing them to default, regardless of whether a financial shock actually occurs.

Implication 2: Although our model analyses firms with one investment project (i.e., a singleproject firm), Proposition 1 is applicable to multi-project firms.

Implication 2 is a natural extension of the model's prediction for single-project firms to multi-project firms. If multi-project firms mainly finance their investment using short-term bonds (i.e., a large average value of $\alpha$ ) and if the maturity length of short-term bonds is short on average (or many short-term bonds mature within a short period of time), a shock to the short-term debt market (e.g., investors anticipate a financial crisis and thus withdraw from the short-term debt market) would increase rollover losses of short-term debt (which are absorbed by equity) and might cause firms to run out of cash and eventually bankrupt. We observe this phenomenon happening during the recent global financial crisis of 2007 when firms had great difficulties in rolling over their maturing short-term debt following 
deteriorating liquidity conditions in the corporate bond markets (see e.g., Dick-Nielsen, Feldhütter, \& Lando, 2012), resulting in a shock to the real economy.

\subsection{Theoretical predictions}

Based on the matching principle, long-term assets should be financed using long-term debt, while short-term assets should be financed using short-term debt. Theory suggests two interrelated explanations for the prediction that firms with longer debt maturity tend to have the longer maturity of assets. First, a firm's rollover risk is a decreasing function of debt maturity, conditional on corporate capital structure. ${ }^{10}$ For example, firms with shorter debt maturity are more exposed to liquidity shocks to debt markets (e.g., collapses of commercial paper or corporate bond markets) ${ }^{11}$ than firms with longer debt maturity. Hence, relative to firms with shorter debt maturity, firms with longer debt maturity will be able to hold longerterm assets. Second, given rollover risk of short-term debt, a firm's bankruptcy is a decreasing function of debt maturity, conditional on corporate capital structure. ${ }^{12}$ Hence, firms that have a shorter debt maturity and a higher likelihood of bankruptcy should hold more short-term assets. Thus, due to both rollover risk and bankruptcy risk, firms with shorter debt maturity should hold more short-term assets (or a shorter asset maturity).

\footnotetext{
${ }^{10}$ See, e.g., Acharya and Skeie (2011), Cheng and Milbradt (2012) and He and Xiong (2012) for a discussion of rollover risk.

${ }^{11}$ See, e.g., Ericsson and Renault (2006) and Bao, Pan, and Wang (2011) for a discussion of illiquidity of corporate bonds and Dick-Nielsen, et al. (2012) for evidence of hikes in illiquidity of corporate bonds during the global financial crisis of 2007-2009.

${ }^{12}$ See, e.g., Leland and Toft (1996) for a discussion of bankruptcy costs and optimal capital structure.
} 
As discussed in the literature, there are two types of firms that might be able to issue short-term debt: (1) high credit-quality firms, and (2) very low credit-quality firms. The high credit-quality firms can issue a wide maturity range of debt (from a very short end to a very long end), while the low credit-quality firms generally cannot obtain a long-term debt. As a result, the low credit-quality firms are most likely forced to finance both short- and long-term assets using short-term debt.

Compared to the high credit-quality firms, the low credit-quality (and/or young) firms have to pay a higher cost of debt (at all debt maturities). Hence, they naturally have to invest in projects with ex ante higher expected returns (and higher risk) than the high credit-quality firms. That is, the low credit-quality firms have the higher costs of debt and hence will have the upward pressure on corporate risk-taking, relative to the high credit-quality firms.

Based on the above discussion, our main prediction is then that debt maturity determines the level of corporate risk-taking, which subsequently affects firm performance volatility in the future. That is, firms with shorter (longer) debt maturity have higher (lower) corporate risk-taking and subsequently higher (lower) future firm performance volatility. It should be noted that while this prediction is similar to that of our theoretical model in Section 2.2, it is based on arguments that are different from that of our theoretical model. The reason is that our theoretical argument in Section 2.2 depends on the prediction that shortening debt maturity in a firm's debt structure lowers a success investment threshold (i.e., a smaller value of $\bar{\theta}$ ). A lower investment threshold implies that a firm invests in riskier projects (e.g., projects with lower probabilities of yielding $R$ ). Our theoretical prediction in this subsection is also based on the idea that if the low credit-quality firms have a higher cost of capital, they would have to invest in riskier projects.

If agency problems are more severe for larger firms than smaller firms, the impact of debt maturity on future firm performance volatility will be larger for larger firms. That is, 
since larger firms typically have a larger capacity to hold riskier assets than smaller firms, firm performance volatility will be higher for larger firms than smaller firms when the larger firms overinvest more than the smaller firms.

A competing hypothesis is that, as discussed above, because the small and low-credit quality firms have the higher cost of debt at any given level of leverage than the large and high-credit quality firms, the small and low-credit quality firms have to hold riskier assets with ex ante higher expected returns than large and high-credit quality firms. This implies that future performance volatility is higher for the smaller firms than for the larger firms.

It should be noted that while terms such as corporate risk-taking and firm performance volatility have often been used almost interchangeably in the empirical literature (see e.g., Faccio, et al., 2011), they are subtly different. A key difference between the two is that corporate risk-taking theoretically refers to a level of risk inherent in the investment that the firm takes ex ante, while firm performance volatility is an ex post "empirical and indirect" measure of a level of risk inherent in the investment that the firm previously took.

So far, in our theoretical analysis, we argue that debt maturity determines the current level of corporate risk-taking, which will in turn affect future firm performance volatility. In sum, we propose four testable hypotheses:

Hypothesis 1: Debt maturity negatively correlates with future firm performance volatility. Precisely, the fraction of long-term debt to total debt is negatively related to future firm performance volatility.

Hypothesis 2: The relationship between debt maturity and future firm performance volatility is non-linear. More specifically, the effect of the fraction of long-term debt to total debt on future firm operating performance volatility is non-linear. 
Hypothesis 3a (Agency problems): The relationship between debt maturity and future firm performance volatility is more pronounced for larger firms than for smaller firms.

Hypothesis 3b (Costs of capital): The relationship between debt maturity and future firm performance volatility is more pronounced for smaller firms than for larger firms.

Hypothesis 4: The relationship between debt maturity and future firm performance volatility is more pronounced for firms with larger growth opportunities than for firms with smaller growth opportunities.

\section{Data and methodology}

\subsection{Data and sample construction}

Our initial sample comprises all publicly listed non-financial firms in 10 countries Brazil, Germany, Indonesia, Japan, Malaysia, South Korea, Switzerland, Thailand, the United Kingdom, and the United States over the period 1991-2013. We retrieve firm-level and country-level data during the period 1991-2013 from Thomson Reuters Datastream. We seek to ensure firms included in our final sample have a minimum of four-year observations, so that a measure of a firm's future performance volatility, which is defined as a three-year moving standard deviation of firm performance (e.g., ROA and Tobin's Q), can be computed for each firm in the sample at time $t+3$ and observations for explanatory variables at time $t$. As a result, our initial sample includes all non-financial firms ${ }^{13}$ over the sample period but excludes all IPOs from January 1, 2010 to December 31, 2013. In addition, we exclude

\footnotetext{
${ }^{13}$ We exclude firms classified in the following industries: banks, financial services, life insurance, non-life insurance, and unclassified industries, according to the industry classification of Thomson Reuters Datastream.
} 
observations with missing data on total assets, earnings before interest and taxes, sales, total debt and long-term debt.

\subsection{Methodology and key variables}

We measure a firm's performance volatility at time $t$ using two measures: (1) firm operating performance volatility, which is computed as the three-year moving standard deviation of return on assets (ROA), and (2) firm value volatility, which is computed as the three-year moving standard deviation of Tobin's Q. We compute ROA as the ratio of earnings before interest and taxes (EBIT) to total assets (in \%) and Tobin's Q as the sum of the market value of equity and the book value of total debt scaled by the book value of total assets. Some scholars use the country-adjusted firm performance volatility. For instance, Bruno and Shin (2014) compute the degree of corporate risk-taking as the five-year standard deviation of country-year adjusted EBITDA/assets.

Following Aivazian, et al. (2005), Zheng, El Ghoul, Guedhami, and Kwok (2012), BenNasr, Boubaker, and Rouatbi (2015) and Díaz-Díaz, García-Teruel, and Martínez-Solano (2016), we measure a firm's debt maturity (DEBTMAT) as the percentage of long-term debt in total debt. ${ }^{14} \mathrm{~A}$ high value of DEBTMAT, which indicates the high proportion of long-term debt to total debt and thus a longer debt maturity, decreases a firm's rollover risk. Due to data limitations for a multi-country sample, we are unable to have a detailed debt maturity breakdown such as that of Keefe and Yaghoubi (2016). Some scholars (e.g., R. Huang, Tan, \& Faff, 2016) note that there is no reason to believe that one particular proxy for debt maturity is superior to others.

\footnotetext{
${ }^{14}$ The portion of long-term debt that is due within one year is categorized as "short-term debt" and thus is not included in "long-term debt"
} 
We include several firm-level control variables to control for firm-specific characteristics that may affect firm performance volatility. Since larger firms are more likely to have better resources and capability to take on riskier investment than smaller firms, we include firm size to control for this effect. Firm size (SIZE) is computed as the natural logarithm of real total assets in million US dollars. ${ }^{15}$ Highly leveraged firms are more likely to investment in riskier projects. We use the ratio of total debt to total assets to proxy for financial leverage (LEV). To control for liquidity, we use the current asset ratio (CACL), which is measured as the ratio of current assets to current liabilities. To control for growth opportunities, we use the marketto-book ratio (MBV), which is computed as the ratio of the market value of equity to the book value of equity. Firms with high profitability are under less pressure to improve their profitability and consequently may not have to invest in riskier projects. To control for the profitability effect, we use return on assets (ROA), which is computed as earnings before interest and taxes (EBIT) scaled by total assets (in \%). To control for firms' long-term investments, we use the capital investment rate (CAPEXTA), which is computed as the ratio of capital expenditures to one-year lagged total assets.

We include a number of industry- and country-level control variables to account for industry and macroeconomic effects. Industry stock returns, which are computed as the first difference in the natural logarithm of the industry stock price index associated with a firm (i.e. the level 2 of the Datastream Global industry price index), are used as an industry-level variable to control for the industry effects (in our robustness check section, we also include industry-year interactions to control for the time-varying industry effects).

We use the GDP growth rate, banking sector development, and export intensity to control for macroeconomic effects. The GDP growth rate ( $\Delta \mathrm{GDP})$ is the annual growth rate of GDP. Export intensity (LNEXPORT) is measured as the natural logarithm of the share of

\footnotetext{
${ }^{15}$ We deflate the book value of total assets in USD by US CPI (CPI $=100$ in 2010).
} 
export to GDP, while banking sector development (LNBSD) is measured as the natural logarithm of the percentage share of domestic credit to private sector by banks to GDP.

\subsection{Descriptive statistics}

We report key summary statistics for all firm-level variables for the final sample of 95,240 firm-year observations in Table 1. To address potential data error and outliers, all variables are winsorized at the 1 st and 99th percentiles. The mean value of SDROA is 4.83 , while the mean value of SDTBQ is 0.26 . The mean value of DEBTMAT is $53.07 \%$, which is smaller than those reported by prior studies such as Datta, et al. (2005) who find that the mean value of DEBTMAT for a sample of 6,246 firm-year observations of U.S. firms from 1992 to 1999 is $78.54 \%$. The mean value of LEV is $25.59 \%$, which is roughly in line with prior studies. For example, Khurana and Wang (2015) report that the mean leverage for a sample of U.S. firms during the period $1985-2007$ is $25.7 \%$.

[INSERT TABLE 1 ABOUT HERE]

[INSERT TABLE 2 ABOUT HERE]

[INSERT FIGURE 1 ABOUT HERE]

Figure 1 illustrates graphically the time-series pattern of the cross-sectional average value of debt maturity (DEBTMAT), firm operating performance volatility (SDROA), and firm value volatility (SDTBQ) for firms in the final sample $(N=95,240)$ over the period 1993-2013. We observe that there is a decreasing trend of debt maturity from 1993 to 2008. That is, the average value for DEBTMAT falls about $21.78 \%$ from $63 \%$ in 1993 to $49 \%$ in 2008. Over the same period, the average value for SDROA increases by about $69 \%$ from 3.07 in 1993 to 5.21 in 2008. In addition, the mean value for SDTBQ increases by about $38 \%$ from 
0.25 in 1993 to 0.34 in 2008. The mean values for SDROA and SDTBQ fall slightly after the onset of the global financial crisis of 2008. Taken together, these patterns point to a negative relationship between debt maturity and firm performance volatility.

We report summary statistics for small firm and large firm subsamples in Panels A and B of Table 2, respectively. We define a large firm (LARGE) based on the book value of real total assets using the cross-sectional median of the book value of real total assets in a country. LARGE is a binary variable that takes a value of one for observations for which the book value of real total assets is larger than the cross-sectional median of the book value of real total assets in a country, and zero otherwise. We find that the mean value of firm operating performance volatility (SDROA) is higher for smaller firms than for larger firm (i.e., 6.97 vs. 3.51). This difference is statistically significant at the $1 \%$ level based on $t$-test and Welch $F$ test. In addition, the difference in the mean value of firm value volatility (SDTBQ) between smaller firms and larger firms (0.35 vs. 0.21$)$ is statistically significant. In addition, the mean value of ROA differs significantly between smaller firms and larger firms (0.98\% vs. $6.46 \%)$. These results suggest that the smaller firms have higher risk but lower profitability than the larger firms do.

The mean value of DEBTMAT is lower for the smaller firms than for the larger firms (44.34 vs. 58.42). The difference in the mean value of debt maturity for the two groups of firms is statistically significant based on $t$-test and Welch $F$-test at the $1 \%$ level. This finding indicates that the smaller firm on average has higher rollover risk (i.e., refinancing) than the larger firm does. Together with the fact that the smaller firms have higher firm performance volatility, the lower mean value of risk for the smaller firms implies that firms with higher rollover risk (e.g., when firms have a smaller fraction of long-term debt to total debt) appear to have higher levels of "ex ante" corporate risk-taking. These results suggest that variation in risk (SDROA and SDTBQ) is probably driven by debt maturity. Overall, our analysis, 
however, does not account for potential changes in firm characteristics over time. We address this issue in Section 4 where we estimate a series of panel regressions.

Table 3 presents pair-wise correlation coefficients for the firm-level variables. As hypothesized, the correlation between SDROA and DEBTMAT is negative and highly significant ( $p$-value $<0.01)$. However, the correlation between SDTBQ and DEBTMAT is positive and highly significant $(p$-value $<0.01)$. Correlation coefficients for all explanatory variables are generally below 0.30 ; therefore, multicollinearity is not of great concern in this study. ${ }^{16}$ Since LNTA are LNCAP are highly correlated, we use LNTA to proxy for firm size.

\section{[INSERT TABLE 3 ABOUT HERE]}

\section{Empirical results}

4.1 Multivariate evidence on the effect of debt maturity on future firm performance volatility

To test our prediction that debt maturity positively correlates with future firm performance volatility, we estimating a series of the panel OLS regressions as follows.

$$
\operatorname{PERFVOL}_{i, j, t}=b_{0}+b_{1} \operatorname{DEBTMAT}_{i, j, t-3}+\delta \mathbf{F}_{i, j, t-3}+\gamma \mathbf{C}_{j, t}+u_{i}+v_{t}+\varepsilon_{i, j, t},
$$

\footnotetext{
${ }^{16}$ Low correlations among the independent variables mean that the efficiency of the OLS estimation of the fixed-effects model is less likely to be affected by the correlations between the independent variables.
} 
where PERFVOL $\mathrm{i}_{\mathrm{j}, \mathrm{t}, \mathrm{t}}$ denotes the operating performance volatility indicator of firm $i$ in country $j$ at time $t$, which is measured as SDROA, computed as the three-year rolling standard deviation of ROA. This measure is also known as corporate risk-taking. As a robustness check, we also use SDTBQ, which is the three-year rolling standard deviation of Tobin's $\mathrm{Q}$, to measure firm value volatility. $\mathrm{DEBTMAT}_{\mathrm{i}, \mathrm{j}, \mathrm{t}-3}$ denotes debt maturity of firm $i$ in country $j$ at time $t-3 . \mathbf{F}_{\mathrm{i}, \mathrm{j}, \mathrm{t}-3}$ is a vector of firm-level control variables at time $t-3 ; \mathbf{C}_{\mathrm{j}, \mathrm{t}-1}$ is a vector of industry- and country-level control variables at time $t ; u_{i}$ is the firm-fixed effects; and $v_{t}$ is the period-fixed effects. All firm-level explanatory variables are three-period lagged in order to control for endogeneity concerns and to establish causality running from debt maturity to future firm performance volatility. While our approach is similar in spirit to that of Faccio, et al. (2011) and Bruno and Shin (2014), a key difference between ours and theirs is that their measure of firm performance volatility at time $t$ (i.e., from time $t$ to $t+4$ ) and their explanatory variables at time $t$ are slightly overlapped, while our measures do not overlap (i.e., firm performance volatility at time $t$ is estimated based on, e.g., ROA from time $t-2$ to $t$ while the explanatory variables are at time $t-3$ ). Therefore, our estimation approach examines the impact of debt maturity on future firm performance volatility.

To control for unobserved firm-specific time invariant effects and unobserved time variant effects, we add firm-fixed effects and year-fixed effects in all panel OLS regressions. We cluster standard errors, which are robust to heteroskedasticity and serial correlation, at the firm level. Country-fixed effects (as well as industry-fixed effects) are included in some models to test the robustness of our results.

[INSERT TABLE 4 ABOUT HERE] 
Table 4 reports the estimates of panel OLS regressions with SDROA as the dependent variable. In column (1), we include our main variable of interest, DEBTMAT, a set of firmlevel control variables, firm fixed effects and period fixed effects. As mentioned earlier, to establish the causal effect running from debt maturity to future firm operating performance volatility, we lag all right-hand firm-level variables three periods (i.e. at time $t-3$ ).

The coefficient on DEBTMAT is negative and statistically significant at the $1 \%$ level, providing empirical support to hypothesis 1 . Consistent with prior studies such as Faccio, et al. (2011) and Bruno and Shin (2014), we find that leverage (LEV) is associated with future firm operating performance volatility. In contrary to Faccio, et al. (2011), we document that ROA has a negative effect on future operating performance volatility. That is, firms with higher profitability tend to have lower future operating performance volatility. This finding implies that firms that are not under pressure to improve their profitability tend to have lower levels of corporate risk-taking with respect to investment decisions and consequently have lower future operating performance volatility. The results further show that capital investment (CAPEXTA), firm size (LNTA), the current ratio (CACL), the fixed assets ratio (FATA), and growth opportunities (MBV) have a positive effect on future firm operating performance volatility.

In column (2), we add industry- and country-level variables to control for industry and macroeconomic effects and find that the coefficient on DEBTMAT is still negative and statistically significant at the $1 \%$ level. In terms of the economic significance, given the estimated coefficient of DEBTMAT of -0.008 (see column (2)), the standard deviation of DEBTMAT of 33.50 and the mean of SDROA of 4.83 (see Table 1), an increase of one standard deviation in DEBTMAT would reduce SDROA by about -0.055 or $5.5 \%(=-0.008$ $\times 33.50 / 4.83)$ at the mean. We do not lag the industry- and country-level variables because we want to control for the contemporaneous relation between industry- and macroeconomic 
factors and firm operating performance volatility. Inconsistent with Bruno and Shin (2014), we find that the GDP growth rate is negatively associated with firm operating performance volatility. The negative and significant coefficient on INDRETURN suggests that industrylevel investment opportunities (measured by the industry stock return) negatively correlate with firm operating performance volatility. The coefficient on LNBSD, which is the natural logarithm of the percentage share of domestic credit to private sector by banks to GDP, is negative and statistically significant, indicating that future firm operating performance volatility is negatively correlated with the level of banking sector development. The coefficient on LNEXPORT is positive and statistically significant, implying that when a country performs well in terms of export performance, firms are more likely to take on riskier investment projects that result in higher degrees of future firm operating performance volatility.

In column (3), we replace the firm fixed effects with a set of country dummies to control for unobserved time-invariant country effects. We still find the negative and significant effect of DEBTMAT. In column (4) we replace countries dummies with the firm fixed effects and the interaction between country dummies and YEAR, which is a time trend variable. The coefficient on DEBTMAT remains negative and statistically significant at the $1 \%$ level in column (4). The magnitude of the estimated coefficients on DEBTMAT is almost identical across four models, implying the stability of the estimations. Overall, the results in Table 4 suggest that debt maturity can significantly explain variation in future firm operating performance volatility.

[INSERT TABLE 5 ABOUT HERE] 
To test the robustness of our result, we replace SDROA with SDTBQ as a proxy for firm performance volatility. Table 5 reports the estimates of panel OLS regressions with SDTBQ as the dependent variable. We find that the coefficient on DEBTMAT is positive but statistically insignificant in all models. As Tobin's Q measures firm value, our results in Table 5 provide no evidence for the effect of debt maturity on the volatility of future firm value. The insignificant relationship between debt maturity and future firm value volatility appears to suggest that investors do not use debt maturity as a primary proxy for an investment's riskiness; therefore, debt maturity is not associated with future firm value volatility. This interpretation is supported by the fact that capital investment (CAPEXTA) and leverage (LEV) have a positive effect on future firm value volatility, suggesting that investors have information on a firm's investments. The results suggest that growth opportunities (MBV) and gross profit margin (GPM) have a positive effect on future firm value volatility. In addition, firm size (LNTA), the current ratio (CACL) and the fixed assets ratio (FATA) have a negative effect on future firm value volatility.

\subsection{Conditions under which debt maturity affects future firm performance volatility}

To test hypotheses $2,3 \mathrm{a}, 3 \mathrm{~b}$, and 4 , we separately add three interaction terms in panel OLS regressions. ${ }^{17}$ In columns (1) and (3) of Table 6, we interact DEBTMAT with DEBTMAT (i.e., the squared term of DEBTMAT). The coefficient on the squared term of DEBTMAT in column (1) is not statistically significant, providing no evidence for the nonlinear effect of debt maturity on future firm operating performance volatility. As the

\footnotetext{
${ }^{17}$ Since the basic findings are robust to controlling for country-fixed effects, industry-fixed effects, time-varying country effects, and time-varying industry effects, we report only specifications with firm-fixed effects and year-fixed effects to conserve space.
} 
coefficient on the squared term of DEBTMAT in column (4) is positive and statistically insignificant, the results do support the idea that the relationship between debt maturity and future firm value volatility is non-linear. The findings provide no empirical support to Hypothesis 2.

\section{[INSERT TABLE 6 ABOUT HERE]}

In columns (2) and (5) of Table 6, we interact DEBTMAT with firm size (LNTA). The estimated coefficient on DEBTMAT in column (2) is positive and statistically significant, but the estimated coefficient on the interaction term between DEBTMAT and LNTA in column (5) is positive and statistically insignificant. These results indicate that the negative effect of debt maturity on future firm operating performance volatility is weaker for larger firms than for smaller firms. These results do not provide empirical support to hypothesis $3 \mathrm{a}$ and $3 \mathrm{~b}$.

In columns (3) and (6), we interact DEBTMAT with MBV. The coefficient on the interaction term in column (3) is positive and statistically significant, suggesting that growth opportunities moderate the impact of debt maturity on future firm operating performance volatility. However, the coefficient on the interaction term in column (6) is not statistically significant, indicating that growth opportunities do not moderate the effect of debt maturity on future firm value volatility. While these results suggest that growth opportunity moderate the negative effect of debt maturity on future firm operating performance volatility, they do not provide empirical support to hypothesis 4 predicting that the relationship between debt maturity and future firm performance volatility is more pronounced for firms with high growth opportunities than for firms with low growth opportunities. 


\subsection{The effect of debt maturity on future firm performance volatility for developing and developed countries}

To test whether the effect of debt maturity on future firm performance volatility differs between firms in developed and firms in developing countries, we interact the DEBTMAT with a developed country (DEV) variable, which takes a value of one for firms listed in a developed country, and zero otherwise. Columns (1) and (2) of Table 7 report the estimates of panel OLS regressions with SDROA and SDTBQ as the dependent variables, respectively. The coefficient on the interaction term between DEBTMAT and DEV is statistically significant only at the $10 \%$ level in column (1) and is not statistically significant in column (2). These results imply that the effect of debt maturity on future firm performance volatility does not differ between firms in developing countries and firms in developed countries.

\section{[INSERT TABLE 7 ABOUT HERE]}

We also estimate Equation (18) separately for both the developing country sample and the developed country sample. In untabulated results, we find that the magnitude and statistical significance of the coefficient on DEBTMAT is almost identical for the developing country sample and the developed country sample. Thus far, we find no evidence to suggest that the negative impact of debt maturity on future firm operating performance volatility differs across firms in developing countries and firms in developed countries.

\subsection{The effect of debt maturity on future firm performance volatility for sub-periods}

We now test whether the effect of debt maturity on future firm performance volatility varies over time. More importantly, we use the fact that our sample period includes the global 
financial crisis, in which firms experienced liquidity shocks in the financial markets, as a natural experience to test whether shorter debt maturity due to liquidity constraints (and better monitoring) is associated with higher quality investment projects (see e.g., Rajan \& Winton, 1995; Stulz, 2000). More precisely, during the global financial crisis period, shorter debt maturity should lead to lower future performance volatility; that is, the coefficient on DEBTMAT should be positive. To this end, we divide our sample period into three periods: (1) the pre-IT bubble burst period (i.e., 1991-2000), the pre-global financial crisis period (i.e., 2001-2006), and the global financial crisis period (i.e., 2007-2013). We estimate our main specification for each period separately.

\section{[INSERT TABLE 8 ABOUT HERE]}

Table 8 reports the estimates of panel OLS regressions with future firm operating performance volatility (SDROA) as the dependent variable in columns (1), (2), and (3) and future firm value volatility (SDTBQ) as the dependent variable in columns (4), (5), and (6). The results show that the effect of debt maturity on future firm operating performance volatility is insignificant during the pre-20001 period and is negative during both the period 2001-2006 and the period 2007-2013. These results do not support the view that during the global financial crisis period shorter debt maturity is associated with better investment projects (with lower risk). Consistent with the results in Table 5, we find the effect of debt maturity on future firm value volatility is insignificant in two of the three subperiods.

\subsection{Robustness checks}

\subsubsection{Alternative measures of firm performance volatility}


Thus far, our measures of firm performance volatility are (1) firm operating performance volatility, which is measured as the three-year moving standard deviation of ROA, and (2) firm value volatility, which is measured as the three-year moving standard deviation of Tobin's Q. As the three-year rolling standard deviations of ROA and Tobin's Q may suffer from extreme values, we alternatively use the five-year rolling standard deviations of ROA and Tobin's Q to proxy for firm performance volatility. We estimate our main panel OLS regressions again using the five-year rolling standard deviations of ROA (SDROA2) and Tobin's Q (SDTBQ2) as the dependent variable.

\section{[INSERT TABLE 9 ABOUT HERE]}

Table 9 reports the estimates of panel OLS regressions with SDROA2 as the dependent variable in columns (1), (2), and (3) and with SDTBQ2 as the dependent variable in columns (4), (5), and (6). All firm-level right hand variables are five periods lagged. The results show that the coefficient on DEBTMAT is negative and statistically significant in columns (1), (2) and (3) and is statistically insignificant in columns (4), (5) and (6). These results indicate that the effect of debt maturity on future firm operating performance volatility remains negative and statistically significant, while the effect of debt maturity on future firm value volatility is not evident. We observe that the moderating effects of firm size and MBV are no longer evident. We find that Overall, our main findings are robust to the alternative measures of firm performance volatility.

\subsubsection{A subsample of high quality firms}

Since low quality firms may not be able to issue long-term debt and have to rely on short-term debt to finance both low and high quality (high and low risk) projects, we conduct 
additional tests by removing low-quality firms from the sample. We conceptually define high quality firms as those with low financial leverage, long-term debt and positive profitability (measured as ROA). We create a low leverage dummy (LOWLEV) variable which takes a value of one for any firm-year observation with financial leverage lower than the crosssectional mean of financial leverage at a country level, and zero otherwise. Following the work of Kahl, Shivdasani, and Wang (2015), showing that very large firms are able to issue commercial paper, we use a large firm (LARGE) dummy variable based on the book value of real total assets using the cross-sectional median of the book value of real total assets in a country as another classification criterion. We create a positive long-term debt (PLTD) dummy variable which takes a value of one for any firm-year observation with a positive value of long-term debt, and zero otherwise.

We estimate our panel OLS specifications for a subsample with $\operatorname{LOWLEV}_{\mathrm{t}-3}=1$, $\operatorname{PLTD}_{\mathrm{t}^{-3}}=1, \mathrm{LARGE}_{\mathrm{t}-3}=1$ and $\mathrm{ROA}_{\mathrm{t}-3}>0$. Given these selection restrictions, we have a small subsample of 6,145 firm-year observations, involving 2,201 firms. To conserve space, we do not tabulate the results. We find that when future firm operating performance volatility is used as the dependent variable, the coefficient on DEBTMAT remains negative but is statistically significant only at the $10 \%$ level. When future firm value volatility is the dependent variable, the coefficient is negative but statistically insignificant.

This set of robustness test shows that for high quality firms which can issue both shortand long-term debt, an increase in debt maturity appears to be associated with a lower level of future firm operating performance volatility but has no effect on future firm value volatility.

\subsubsection{A subsample of firms with new long-term debt}


As our measure for debt maturity represents debt issuance decisions of firms over time, we additionally test the robustness of our results to controlling for a more recent financing decision. More specifically, we focus on a sample of firms that have an increase in capital expenditure and move from having no long-term debt to having long-term debt.

We estimate our main regression for a subsample with CAPEXTA $_{t-3}>0, \operatorname{PLTD}_{t-4}=0$ and $\operatorname{PLTD}_{\mathrm{t}-3}=1$. This subsample represents a sample of firms that do not have long-term debt at time $t=-4$, have a capital investment at time $t=-3$ and have long-term debt at time $t$ $=-3$. Given these selection restrictions, we have a sample of 17,756 firm-year observations, involving 7,255 firms. Our untabulated results show that the effect of DEBTMAT on future firm operating performance volatility is still negative and statistically significant. The effect of DEBTMAT on future firm value volatility remains statistically insignificant.

This set of robustness tests shows that for firms which did not have long-term debt in the previous year but have capital expenditures and long-term debt in the current year, an increase in debt maturity is negatively associated with future firm operating performance volatility but is not associated with future firm value volatility.

\subsubsection{SLS regressions}

If debt maturity and corporate risk-taking are jointly determined, then OLS estimation can lead to a biased coefficient on DEBTMAT. To address this concern, we follow the literature by employing a two-stage least squares (2SLS) estimation. In the first stage, we estimate an OLS regression for debt maturity. In the second stage, we estimate an OLS regression for future firm performance volatility by using the predicted value of DEBTMAT from the first-stage regression as an explanatory variable. For the first-stage regression, we estimate the following panel OLS model: 


$$
\operatorname{DEBTMAT}_{i, j, t}=c_{0}+c_{0} \operatorname{MEANDEBTMAT}_{j, t-1}+\delta \mathbf{F}_{i, j, t-1}+\gamma \mathbf{C}_{j, t-1}+u_{i}+v_{t}+\varepsilon_{i, j, t},
$$

where MEANDEBTMAT is the country-year mean value of debt maturity, and all variables are defined as before. All explanatory variables are one-period lagged. Firm-fixed effects and year-fixed effects are included in the model. We then use the predicted value of debt maturity obtained from Equation (19) as a measure of debt maturity in the second-stage regression as follows:

$$
\operatorname{PERFVOL}_{i, j, t}=d_{0}+d_{1} \operatorname{PREDEBTMAT}_{i, j, t-3}+\delta \mathbf{F}_{i, j, t-3}+\gamma \mathbf{C}_{j, t}+u_{i}+v_{t}+\varepsilon_{i, j, t},
$$

where PDEBTMAT is the predicted value of debt maturity obtained from Equation (19). We include firm-fixed effects and year-fixed effects in the second-stage regressions.

Table 10 reports the second-stage results of our two-stage least squares estimation (i.e. of Equations (19) and (20)). ${ }^{18}$ In columns (1)--(4), firm operating performance volatility is the dependent variable. The results in columns (1)--(4) are very similar to those reported in Tables 4 and 6 . The effect of debt maturity on firm operating performance volatility remains negative and statistically significant. However, we no longer find that MBV moderates the effect of debt maturity on future operating performance volatility. In columns (5)--(8), firm value volatility is the dependent variable. We still find that the effect of debt maturity on future firm value volatility is not statistically significant. Overall, the results of 2SLS

\footnotetext{
${ }^{18}$ The $R^{2}$ of the first-stage regressions suggest that our instrumental variables satisfy the relevancy conditions; exclusion tests show that the instrumental variables are jointly significant $(p$-value $<0.01)$.
} 
regressions further indicate that debt maturity has a negative effect on future operating performance volatility.

\section{[INSERT TABLE 10 ABOUT HERE]}

Thus far, we show that our results are insensitive to the inclusion of firm-fixed effects, year-fixed effects, country-fixed effects, and/or country-year interactions (see Tables 4 and 5). In our main analysis, we use the industry stock return to control for the industry effect. We additionally test whether industry effects drive our results by adding (1) industry dummies ${ }^{19} \times$ YEAR, which capture the annual variation in the average future firm performance volatility by industry, regardless of where firms are located, and (2) country dummies $\times$ YEAR, which capture the differential effect of business/economic cycles by country, in the same specification as those in Tables 4 through 8 . To conserve space, we do not tabulate results. We find that our main results are largely unaltered when we include industry-year interactions and country-year interactions in the specification.

\section{Conclusion}

Corporate debt structure maturity has been the subject of interest in corporate finance. One issue that has received significant attention in the aftermath of financial crises (e.g., the Asian financial crisis of 1997 and the global financial crisis of 2007) is that there is a substantial mismatch between asset maturity and debt maturity. More importantly, firms tend

\footnotetext{
${ }^{19}$ For ease of comparison, we classify each firm into a specific industry using a Level 2 classification (i.e., the business sector) of the Thomson Reuters Business Classification (TRBC) system, consisting of 28 business sectors.
} 
to finance long-term assets with shorter debt maturity. In this paper, we address the question of whether debt maturity can explain variation in future firm performance volatility.

We build a simple two-period model to analyze the effect of debt maturity on the riskiness of corporate investment. In doing so, we make a number of simplifying assumptions. Relaxing many assumptions does not alter the basic insights derived from the model. Our model suggests that the investment threshold (i.e., the investment's probability of success) is lower when the proportion of short-term debt in total debt increases, implying that corporate risk-taking (i.e., the riskiness of investment) is a decreasing function of debt maturity. Using the idea that an investment's risk can be measured as volatility of performance, we argue that debt maturity, which is associated with corporate risk-taking, correlates with future firm performance volatility. We empirically test our prediction using a sample of firms in 10 countries over the period 1991-2013. To measure future firm performance volatility, we use (1) firm operating performance volatility and (2) firm value volatility. To examine the effect of debt maturity on future firm performance volatility, we employ the panel OLS regressions and test the robustness of our results by using the 2SLS regressions.

Our empirical results show that after controlling for a large set of firm characteristics, industry conditions, and country-level variables, debt maturity has a negative effect on future firm operating performance volatility but has no effect on future firm value volatility. The negative impact of debt maturity on future firm operating performance volatility is smaller for larger firms than for smaller firms. We find empirical evidence for the moderating effect of investment opportunities on the relationship between debt maturity and future firm operating performance as well as future firm value volatility.

The results of our paper provide new evidence that debt maturity and "unobservable" ex ante corporate risk-taking are more likely to be highly correlated, given that debt maturity is 
negatively associated with future firm performance. These findings can have implications for both firms and corporate debt holders. For instance, our findings, by quantifying the relationship between debt maturity and future firm performance volatility, are relevant for banks' loan officers considering loan applications as well as for monetary policymakers.

\section{Acknowledgements}

We are indebted to Carl Chen (Editor) and two anonymous references for helpful comments and suggestions. We are also grateful to participants at the 2016 FMA Annual Meeting (held in Las Vegas) for valuable comments. We gratefully acknowledge financial support from Ishii Memorial Securities Research Promotion Foundation.

\section{References}

Acharya, V. V., Gale, D., \& Yorulmazer, T. (2011). Rollover risk and market freezes. Journal of Finance, 66, 1177-1209.

Acharya, V. V., \& Skeie, D. (2011). A model of liquidity hoarding and term premia in interbank markets. Journal of Monetary Economics, 58, 436-447.

Aggarwal, R. K., \& Samwick, A. A. (2006). Empire-builders and shirkers: Investment, firm performance, and managerial incentives. Journal of Corporate Finance, 12, 489-515.

Aivazian, V. A., Ge, Y., \& Qiu, J. (2005). Debt maturity structure and firm investment. Financial Management, 34, 107-119.

Bao, J., Pan, J. U. N., \& Wang, J. (2011). The illiquidity of corporate bonds. Journal of Finance, 66, 911-946.

Barclay, M. J., \& Smith, C. W., Jr. (1995). The maturity structure of corporate debt. Journal of Finance, 50, 609-631. 
Ben-Nasr, H., Boubaker, S., \& Rouatbi, W. (2015). Ownership structure, control contestability, and corporate debt maturity. Journal of Corporate Finance, 35, 265285.

Bolton, P., Chen, H., \& Wang, N. (2013). Market timing, investment, and risk management. Journal of Financial Economics, 109, 40-62.

Bolton, P., Chen, H. U. I., \& Wang, N. (2011). A unified theory of Tobin's q, corporate investment, financing, and risk management. Journal of Finance, 66, 1545-1578.

Brick, I. E., \& Ravid, S. A. (1985). On the relevance of debt maturity structure. Journal of Finance, 40, 1423-1437.

Brockman, P., Martin, X., \& Unlu, E. (2010). Executive compensation and the maturity structure of corporate debt. Journal of Finance, 65, 1123-1161.

Brown, K., Jha, R., \& Pacharn, P. (2015). Ex ante CEO severance pay and risk-taking in the financial services sector. Journal of Banking \& Finance, 59, 111-126.

Bruno, V., \& Shin, H. S. (2014). Globalization of corporate risk taking. Journal of International Business Studies, 45, 800-820.

Butler, A. W., Cornaggia, J., Grullon, G., \& Weston, J. P. (2011). Corporate financing decisions, managerial market timing, and real investment. Journal of Financial Economics, 101, 666-683.

Cheng, I.-H., \& Milbradt, K. (2012). The hazards of debt: Rollover freezes, incentives, and bailouts. Review of Financial Studies, 25, 1070-1110.

D’Mello, R., \& Miranda, M. (2010). Long-term debt and overinvestment agency problem. Journal of Banking \& Finance, 34, 324-335.

Datta, S., Iskandar-Datta, M., \& Raman, K. (2005). Managerial stock ownership and the maturity structure of corporate debt. Journal of Finance, 60, 2333-2350. 
De Haan, L., \& Sterken, E. (2006). The impact of monetary policy on the financing behaviour of firms in the Euro area and the UK. The European Journal of Finance, $12,401-420$.

Dell'Ariccia, G., \& Marquez, R. (2010). Risk and the corporate structure of banks. Journal of Finance, 65, 1075-1096.

Diamond, D. W. (1991). Debt maturity structure and liquidity risk. Quarterly Journal of Economics, 106, 709-737.

Diamond, D. W., \& He, Z. (2014). A theory of debt maturity: The long and short of debt overhang. Journal of Finance, 69, 719-762.

Díaz-Díaz, N. L., García-Teruel, P. J., \& Martínez-Solano, P. (2016). Debt maturity structure in private firms: Does the family control matter? Journal of Corporate Finance, 37, $393-411$.

Dick-Nielsen, J., Feldhütter, P., \& Lando, D. (2012). Corporate bond liquidity before and after the onset of the subprime crisis. Journal of Financial Economics, 103, 471-492.

Ericsson, J., \& Renault, O. (2006). Liquidity and credit risk. Journal of Finance, 61, 22192250.

Faccio, M., Marchica, M.-T., \& Mura, R. (2011). Large shareholder diversification and corporate risk-taking. Review of Financial Studies, 24, 3601-3641.

Faccio, M., Marchica, M.-T., \& Mura, R. (2016). CEO gender, corporate risk-taking, and the efficiency of capital allocation. Journal of Corporate Finance, 39, 193-209.

Fama, E. F., \& French, K. R. (1993). Common risk factors in the returns on stock and bonds. Journal of Financial Economics, 33, 3-56.

Fan, J. P. H., Titman, S., \& Twite, G. (2012). An international comparison of capital structure and debt maturity choices. Journal of Financial and Quantitative Analysis, 47, 23-56. 
Farhi, E., \& Tirole, J. (2012). Collective moral hazard, maturity mismatch, and systemic bailouts. American Economic Review, 102, 60-93.

Flannery, M. J. (1986). Asymmetric information and risky debt maturity choice. Journal of Finance, 41, 19-37.

González-Urteaga, A., \& Rubio, G. (2016). The cross-sectional variation of volatility risk premia. Journal of Financial Economics, 119, 353-370.

González, V. M., \& González, F. (2014). Banking liberalization and firms' debt structure: International evidence. International Review of Economics \& Finance, 29, 466-482.

Greenwood, R., Hanson, S., \& Stein, J. C. (2010). A gap-filling theory of corporate debt maturity choice. Journal of Finance, 65, 993-1028.

Harford, J., Klasa, S., \& Maxwell, W. F. (2014). Refinancing risk and cash holdings. Journal of Finance, 69, 975-1012.

He, Z., \& Xiong, W. E. I. (2012). Rollover risk and credit risk. Journal of Finance, 67, 391430.

Huang, R., Tan, K. J. K., \& Faff, R. W. (2016). CEO overconfidence and corporate debt maturity. Journal of Corporate Finance, 36, 93-110.

Huang, W., Liu, Q., Ghon Rhee, S., \& Wu, F. (2012). Extreme downside risk and expected stock returns. Journal of Banking \& Finance, 36, 1492-1502.

Jeon, H., \& Nishihara, M. (2015). The effects of business cycle and debt maturity on a firm's investment and default decisions. International Review of Economics \& Finance, 38, $326-351$.

Ju, N., \& Ou-Yang, H. (2006). Capital structure, debt maturity, and stochastic interest rates. The Journal of Business, 79, 2469-2502.

Julio, B., \& Yook, Y. (2012). Political uncertainty and corporate investment cycles. Journal of Finance, 67, 45-84. 
Kahl, M., Shivdasani, A., \& Wang, Y. (2015). Short-term debt as bridge financing: Evidence from the commercial paper market. Journal of Finance, 70, 211-255.

Keefe, M. O. C., \& Yaghoubi, M. (2016). The influence of cash flow volatility on capital structure and the use of debt of different maturities. Journal of Corporate Finance, $38,18-36$.

Khurana, I. K., \& Wang, C. (2015). Debt maturity structure and accounting conservatism. Journal of Business Finance \& Accounting, 42, 167-203.

Leland, H. E., \& Toft, K. B. (1996). Optimal capital structure, endogenous bankruptcy, and the term structure of credit spreads. Journal of Finance, 51, 987-1019.

Li, K., Griffin, D., Yue, H., \& Zhao, L. (2013). How does culture influence corporate risktaking? Journal of Corporate Finance, 23, 1-22.

Myers, S. C. (1977). Determinants of corporate borrowing. Journal of Financial Economics, $5,147-175$.

Myers, S. C., \& Majluf, N. S. (1984). Corporate financing and investment decisions when firms have information that investors do not have. Journal of Financial Economics, $13,187-221$.

Rajan, R., \& Winton, A. (1995). Covenants and Collateral as Incentives to Monitor. Journal of Finance, 50, 1113-1146.

Rampini, A. A., \& Viswanathan, S. (2010). Collateral, risk management, and the distribution of debt capacity. Journal of Finance, 65, 2293-2322.

Rauh, J. D., \& Sufi, A. (2010). Capital structure and debt structure. Review of Financial Studies, 23, 4242-4280.

Stulz, R. M. (2000). Financial Structure, Corporate Finance and Economic Growth. International Review of Finance, 1, 11-38. 
Tinic, S. M., \& West, R. R. (1984). Risk and return: January Vs. the rest of the year. Journal of Financial Economics, 13, 561-574.

Vig, V. (2013). Access to collateral and corporate debt structure: Evidence from a natural experiment. Journal of Finance, 68, 881-928.

Watanabe, A., \& Watanabe, M. (2008). Time-varying liquidity risk and the cross section of stock returns. Review of Financial Studies, 21, 2449-2486.

Zheng, X., El Ghoul, S., Guedhami, O., \& Kwok, C. C. Y. (2012). National culture and corporate debt maturity. Journal of Banking \& Finance, 36, 468-488. 
Table 1. Descriptive statistics for firm-level variables.

This table provides descriptive statistics for firm-level variables for the final sample during 1993-2013. We deflate the nominal value of the time series by US CPI (US CPI $=100$ in 2010). All variables are winsorized at the 1 st and 99th percentiles. $N=95,240$

\begin{tabular}{|c|c|c|c|c|c|}
\hline Variable & Definition & Description & Mean & Median & S.D. \\
\hline SDROA & $\begin{array}{l}\text { Firm operating performance } \\
\text { volatility }\end{array}$ & The three-year moving standard deviation of ROA & 4.83 & 2.51 & 7.18 \\
\hline SDTBQ & Firm value volatility & $\begin{array}{l}\text { The three-year moving standard deviation of Tobin's } \\
\text { Q }\end{array}$ & 0.26 & 0.12 & 0.45 \\
\hline DEBTMAT & Debt maturity & Long-term debt as a percentage of total debt & 53.07 & 55.63 & 33.50 \\
\hline CAPEXTA & Investment ratio & $\begin{array}{l}\text { The ratio of capital expenditure to one-year lagged } \\
\text { total assets (in \%) }\end{array}$ & 5.33 & 3.48 & 6.13 \\
\hline RMKTCAP & Real market capitalization & $\begin{array}{l}\text { Total market capitalization in million US dollars } \\
\text { deflated by US CPI (US CPI = } 100 \text { in 2010). }\end{array}$ & $96,238.14$ & $3,802.61$ & $341,874.19$ \\
\hline LNTA & Firm size & $\begin{array}{l}\text { The natural logarithm of real total assets in million US } \\
\text { dollars }\end{array}$ & 12.93 & 12.78 & 1.96 \\
\hline LNCAP & Firm market value & $\begin{array}{l}\text { The natural logarithm of real market capitalization in } \\
\text { million US dollars }\end{array}$ & 8.05 & 8.17 & 3.00 \\
\hline ROA & Return on assets & $\begin{array}{l}\text { Earning before interest and taxes (EBIT) as a } \\
\text { percentage of total assets }\end{array}$ & 4.38 & 5.52 & 13.34 \\
\hline TBQ & Tobin’s Q & $\begin{array}{l}\text { The sum of the market value of equity and the book } \\
\text { value of total debt scaled by the book value of total } \\
\text { assets }\end{array}$ & 1.11 & 0.82 & 1.03 \\
\hline GPM & Gross profit margin & Gross profit as a percentage of sales & 26.68 & 23.57 & 19.19 \\
\hline
\end{tabular}


Table 2. Descriptive statistics for firm-level variables.

Panels A and B of this table provide descriptive statistics for firm-level variables for a small firm sample and a large firm sample, respectively, during 1993-2013. A large firm (LARGE) dummy variable takes a value of one for observations for which the book value of real total assets is larger than the cross-sectional median of the book value of real total assets in a country, and zero otherwise. SDROA is measured as the three-year moving standard deviation of return on assets (ROA), which is measured as the ratio of EBIT to total assets (in \%). SDTBQ is computed as the three-year moving standard deviation of Tobin's Q (TBQ), which is computed as the sum of the market value of equity and the book value of total debt scaled by the book value of total assets. Debt maturity (DEBTMAT) is measured as longterm debt as a percentage of total debt. Investment ratio (CAPEXTA) is measured as the percentage of capital expenditure to one-year lagged total assets. RTA denotes real total assets in million US dollars. Leverage (LEV) is computed as the percentage share of total debt to total assets. Current ratio (CACL) is the ratio of current assets to current liabilities. Fixed asset ratio (FATA) is computed as the ratio of non-current assets to total assets. The market-to-book ratio (MBV) is computed as the ratio of the market value of equity to the book value of equity. Gross profit margin (GPM) is the ratio of gross profit to sales (in \%). We deflate the nominal value of the time series by US CPI (US CPI = 100 in 2010).

\begin{tabular}{lrrrr}
\hline & Mean & Median & S.D. & N \\
\hline Panel A: Small firms & & & & \\
SDROA & 6.97 & 3.60 & 9.45 & 36,225 \\
SDTBQ & 0.35 & 0.15 & 0.59 & 36,225 \\
DEBTMAT & 44.34 & 43.15 & 33.87 & 36,225 \\
CAPEXTA & 4.76 & 2.63 & 6.34 & 36,225 \\
RTA & 127.38 & 82.10 & 129.70 & 36,225 \\
LNTA & 11.18 & 11.25 & 1.10 & 36,225 \\
CACL & 2.18 & 1.64 & 1.92 & 36,225 \\
FATA & 0.46 & 0.45 & 0.20 & 36,225 \\
LEV & 23.20 & 19.32 & 19.09 & 36,225 \\
MBV & 1.71 & 1.01 & 2.62 & 36,225 \\
ROA & 0.98 & 4.21 & 18.12 & 36,225 \\
TBQ & 1.18 & 0.79 & 1.27 & 36,225 \\
GPM & 26.32 & 23.47 & 21.44 & 36,225 \\
Panel B: Large firms & & & & \\
SDROA & 3.51 & 2.06 & 4.88 & 59,015 \\
SDTBQ & 0.21 & 0.12 & 0.34 & 59,015 \\
DEBTMAT & 58.42 & 62.82 & 32.12 & 59,015 \\
CAPEXTA & 5.68 & 3.98 & 5.98 & 59,015 \\
RTA & 14.01 & $1,083.08$ & $22,619.34$ & 59,015 \\
LNTA & 1.72 & 13.79 & 1.56 & 59,015 \\
CACL & 0.54 & 1.40 & 1.26 & 59,015 \\
FATA & 27.07 & 25.46 & 18.17 & 59,015 \\
LEV & 1.83 & 1.28 & 2.23 & 59,015 \\
MBV & 6.46 & 6.15 & 8.62 & 59,015 \\
ROA & 1.06 & 0.83 & 0.85 & 59,015 \\
TBQ & 26.91 & 23.63 & 17.66 & 59,015 \\
GPM & & & &
\end{tabular}


Table 3. Correlation coefficient matrix of key firm-level variables.

This table presents correlation coefficients for key firm-level variables for the final sample, totaling 95,240 firm-year observations. SDROA is measured as the three-year moving standard deviation of return on assets (ROA), which is measured as the ratio of EBIT to total assets (in \%). SDTBQ is computed as the three-year moving standard deviation of Tobin's Q (TBQ), which is computed as the sum of the market value of equity and the book value of total debt scaled by the book value of total assets. Debt maturity (DEBTMAT) is measured as the ratio of long-term debt to total debt (in \%). Investment ratio (CAPEXTA) is measured as the ratio of capital expenditure to one-year lagged total assets (in \%). Firm size (LNTA) is measured as the natural logarithm of real total assets in million US dollars. Current ratio (CACL) is the ratio of current assets to current liabilities. The fixed asset ratio (FATA) is computed as the ratio of non-current assets to total assets. Leverage (LEV) is computed as the ratio of total debt to total assets (in \%). The market-to-book ratio (MBV) is computed as the ratio of the market value of equity to the book value of equity. Gross profit margin (GPM) is the ratio of gross profit to sales (in \%). All variables are winsorized at the 1st and 99th percentiles. Symbols $* * *, * *$, and $*$ denote significance at the $1 \%, 5 \%$ and $10 \%$ levels, respectively.

\begin{tabular}{|c|c|c|c|c|c|c|c|c|c|c|c|c|c|}
\hline & 1 & 2 & 3 & 4 & 5 & 6 & 7 & 8 & 9 & 10 & 11 & 12 & 13 \\
\hline 1. SDROA & 1.00 & & & & & & & & & & & & \\
\hline 2. SDTBQ & $0.32 * * *$ & 1.00 & & & & & & & & & & & \\
\hline 3. DEBTMAT & $-0.02 * * *$ & $0.05 * * *$ & 1.00 & & & & & & & & & & \\
\hline 4. CAPEXTA & $-0.02 * * *$ & $0.12 * * *$ & $0.17 * * *$ & 1.00 & & & & & & & & & \\
\hline 5. LNTA & $-0.28 * * *$ & $-0.16 * * *$ & $0.35 * * *$ & $0.08 * * *$ & 1.00 & & & & & & & & \\
\hline 6. LNCAP & $-0.24 * * *$ & $-0.12 * * *$ & $-0.08 * * *$ & $0.02 * * *$ & $0.55 * * *$ & 1.00 & & & & & & & \\
\hline 7. CACL & $0.07 * * *$ & $0.19 * * *$ & $0.10 * * *$ & $-0.09 * * *$ & $-0.14 * * *$ & $-0.10 * * *$ & 1.00 & & & & & & \\
\hline 8. FATA & $-0.08 * * *$ & $-0.09 * * *$ & $0.31 * * *$ & $0.30 * * *$ & $0.26 * * *$ & $0.07 * * *$ & $-0.34 * * *$ & 1.00 & & & & & \\
\hline 9. LEV & $0.07 * * *$ & $-0.09 * * *$ & $0.18 * * *$ & $0.07 * * *$ & $0.12 * * *$ & $0.04 * * *$ & $-0.35^{* * *}$ & $0.30 * * *$ & 1.00 & & & & \\
\hline 10. MBV & $0.09 * * *$ & $0.34 * * *$ & $0.12 * * *$ & $0.10 * * *$ & $0.08 * * *$ & 0.00 & $0.02 * * *$ & $-0.01 * * *$ & 0.00 & 1.00 & & & \\
\hline 11. ROA & $-0.44 * * *$ & $-0.16 * * *$ & $0.09 * * *$ & $0.13 * * *$ & $0.25 * * *$ & $0.19 * * *$ & $0.02 * * *$ & $0.04 * * *$ & $-0.15 * * *$ & $0.04 * * *$ & 1.00 & & \\
\hline 12. TBQ & $0.18^{* * *}$ & $0.60 * * *$ & $0.14 * * *$ & $0.14 * * *$ & $-0.04 * * *$ & $-0.04 * * *$ & $0.15^{* * *}$ & $-0.05^{* * *}$ & $-0.01 * *$ & $0.50 * * *$ & 0.00 & 1.00 & \\
\hline 13. GPM & $-0.01 * * *$ & $0.16^{* * *}$ & $0.18 * * *$ & $0.05 * * *$ & $0.09 * * *$ & $-0.03 * * *$ & $0.11 * * *$ & $0.09 * * *$ & $-0.09 * * *$ & $0.17 * * *$ & $0.26 * * *$ & $0.29 * * *$ & 1.00 \\
\hline
\end{tabular}


Table 4. The effect of debt maturity on future firm operating performance volatility.

This table presents the results of panel OLS regressions of future firm operating performance volatility on debt maturity for a sample of non-financial firms. Future firm operating performance volatility (SDROA) is measured as the three-year moving standard deviation of ROA. All firm-level explanatory variables are three-period lagged. $\triangle$ GDP denotes the GDP growth rate (in \%); LNBSD is the natural logarithm of the percentage share of domestic credit to private sector by banks to GDP. LNEXPORT is the natural logarithm of the percentage share of export to GDP; INDRETURN denotes the industry-level stock return (in \%), measured as the first difference in the natural logarithm of the industry price index. YEAR is a time trend variable. All other variables are defined as in Table 1. Standard errors, which are robust to heteroskedasticity and serial correlation, are clustered at the firm level. We report standard errors in parentheses. Symbols $* * *, * *$, and $*$ denote significance at the $1 \%, 5 \%$ and $10 \%$ levels, respectively.

\begin{tabular}{|c|c|c|c|c|}
\hline & (1) & (2) & (3) & (4) \\
\hline \multirow[t]{2}{*}{ DEBTMAT $_{t-3}$} & $-0.008 * * *$ & $-0.008 * * *$ & $-0.006^{* * *}$ & $-0.007 * * *$ \\
\hline & $(0.001)$ & $(0.001)$ & $(0.001)$ & $(0.001)$ \\
\hline \multirow[t]{2}{*}{ CAPEXTA $_{t-3}$} & $0.012 * * *$ & $0.010 * *$ & $0.044 * * *$ & $0.008^{*}$ \\
\hline & $(0.004)$ & $(0.004)$ & $(0.005)$ & $(0.004)$ \\
\hline \multirow[t]{2}{*}{$\mathrm{LNTA}_{\mathrm{t}-3}$} & $0.902 * * *$ & $1.028 * * *$ & $-0.530 * * *$ & $1.087 * * *$ \\
\hline & $(0.060)$ & $(0.061)$ & $(0.021)$ & $(0.063)$ \\
\hline \multirow[t]{2}{*}{$\mathrm{CACL}_{\mathrm{t}-3}$} & $0.116 * * *$ & $0.112 * * *$ & $0.230 * * *$ & $0.098 * * *$ \\
\hline & $(0.028)$ & $(0.028)$ & $(0.025)$ & $(0.028)$ \\
\hline \multirow[t]{2}{*}{$\mathrm{FATA}_{\mathrm{t}-3}$} & $0.649 * *$ & 0.494 & $-1.141 * * *$ & 0.380 \\
\hline & $(0.306)$ & $(0.305)$ & $(0.195)$ & $(0.306)$ \\
\hline \multirow[t]{2}{*}{$\mathrm{LEV}_{\mathrm{t}-3}$} & $0.008 * * *$ & $0.007 * * *$ & $0.017 * * *$ & $0.008 * * *$ \\
\hline & $(0.003)$ & $(0.002)$ & $(0.002)$ & $(0.003)$ \\
\hline \multirow[t]{2}{*}{$\mathrm{MBV}_{\mathrm{t}-3}$} & -0.004 & 0.005 & $0.166 * * *$ & 0.007 \\
\hline & $(0.011)$ & $(0.011)$ & $(0.012)$ & $(0.011)$ \\
\hline \multirow[t]{2}{*}{$\mathrm{ROA}_{\mathrm{t}-3}$} & $-0.025 * * *$ & $-0.026 * * *$ & $-0.156^{* * *}$ & $-0.026 * * *$ \\
\hline & $(0.002)$ & $(0.002)$ & $(0.002)$ & $(0.002)$ \\
\hline \multirow[t]{2}{*}{$\mathrm{GPM}_{\mathrm{t}-3}$} & $-0.021 * * *$ & $-0.021 * * *$ & $0.013 * * *$ & $-0.021 * * *$ \\
\hline & $(0.003)$ & $(0.003)$ & $(0.002)$ & $(0.003)$ \\
\hline \multirow[t]{2}{*}{ INDRETURN $_{\mathrm{t}}$} & & $-0.003 * * *$ & $-0.003 * * *$ & $-0.003 * * *$ \\
\hline & & $(0.001)$ & $(0.001)$ & $(0.001)$ \\
\hline \multirow[t]{2}{*}{ LNBSD $_{t}$} & & $-1.934 * * *$ & $-0.695^{* * *}$ & $-0.667 * * *$ \\
\hline & & $(0.180)$ & (0.194) & $(0.248)$ \\
\hline \multirow[t]{2}{*}{$\mathrm{LNEXPORT}_{\mathrm{t}}$} & & $0.744 * * *$ & $0.910 * * *$ & $1.709 * * *$ \\
\hline & & $(0.250)$ & $(0.272)$ & $(0.362)$ \\
\hline \multirow[t]{2}{*}{$\Delta \mathrm{GDP}_{\mathrm{t}}$} & & $-0.066 * * *$ & $-0.110 * * *$ & $-0.061 * * *$ \\
\hline & & (0.014) & $(0.016)$ & $(0.014)$ \\
\hline Firm fixed effects & Yes & Yes & No & Yes \\
\hline Period fixed effects & Yes & Yes & Yes & Yes \\
\hline Country dummies & No & No & Yes & No \\
\hline Country dummies $\times$ YEAR & No & No & No & Yes \\
\hline Adjusted $R^{2}$ & 0.462 & 0.464 & 0.184 & 0.466 \\
\hline$F$-statistic & $9.089 * * *$ & $9.154 * * *$ & $446.426 * * *$ & $9.196 * * *$ \\
\hline Firms included & 8,593 & 8,593 & 8,593 & 8,593 \\
\hline Observations & 81,120 & 81,120 & 81,120 & 81,120 \\
\hline
\end{tabular}


Table 5. The effect of debt maturity on future firm value volatility.

This table presents the results of panel OLS regressions of future firm value volatility on debt maturity for a sample of non-financial firms. Future firm value volatility (SDTBQ) is measured as the three-year moving standard deviation of Tobin's Q. All firm-level explanatory variables are three-period lagged. INDRETURN denotes the industry-level stock return (in \%), measured as the first difference in the natural logarithm of the industry price index. $\triangle$ GDP denotes the GDP growth rate (in \%); LNBSD is the natural logarithm of the percentage share of domestic credit to private sector by banks to GDP. LNEXPORT is the natural logarithm of the percentage share of export to GDP. YEAR is a time trend variable. All other variables are defined as in Table 1. Standard errors, which are robust to heteroskedasticity and serial correlation, are clustered at the firm level. We report standard errors in parentheses. Symbols ***,**, and * denote significance at the $1 \%, 5 \%$ and $10 \%$ levels, respectively.

\begin{tabular}{|c|c|c|c|c|}
\hline & (1) & $(2)$ & $(3)$ & (4) \\
\hline \multirow[t]{2}{*}{ DEBTMAT $_{\mathrm{t}-3}$} & 0.000 & 0.000 & $0.000 * * *$ & 0.000 \\
\hline & $(0.000)$ & $(0.000)$ & $(0.000)$ & $(0.000)$ \\
\hline \multirow[t]{2}{*}{ CAPEXTA $_{t-3}$} & $0.001 * * *$ & $0.001 * * *$ & $0.002 * * *$ & $0.001 * * *$ \\
\hline & $(0.000)$ & $(0.000)$ & $(0.000)$ & $(0.000)$ \\
\hline \multirow[t]{2}{*}{$\mathrm{LNTA}_{\mathrm{t}-3}$} & $-0.101 * * *$ & $-0.102 * * *$ & $-0.023 * * *$ & $-0.102 * * *$ \\
\hline & $(0.003)$ & $(0.003)$ & $(0.001)$ & (0.003) \\
\hline \multirow[t]{2}{*}{$\mathrm{CACL}_{\mathrm{t}-3}$} & $-0.011 * * *$ & $-0.011 * * *$ & $0.005 * * *$ & $-0.010 * * *$ \\
\hline & (0.002) & (0.002) & $(0.001)$ & (0.002) \\
\hline \multirow[t]{2}{*}{ FATA $_{t-3}$} & $-0.160 * * *$ & $-0.160 * * *$ & $-0.104 * * *$ & $-0.156 * * *$ \\
\hline & $(0.017)$ & $(0.017)$ & $(0.009)$ & (0.017) \\
\hline \multirow[t]{2}{*}{$\mathrm{LEV}_{\mathrm{t}-3}$} & $0.000 * * *$ & $0.000 * * *$ & $-0.001 * * *$ & $0.000 * * *$ \\
\hline & $(0.000)$ & $(0.000)$ & $(0.000)$ & $(0.000)$ \\
\hline \multirow[t]{2}{*}{$\mathrm{TBQ}_{\mathrm{t}-3}$} & $0.087 * * *$ & $0.087 * * *$ & $0.186^{* * *}$ & $0.086 * * *$ \\
\hline & $(0.002)$ & $(0.002)$ & $(0.002)$ & (0.002) \\
\hline \multirow[t]{2}{*}{$\mathrm{ROA}_{\mathrm{t}-3}$} & $-0.001 * * *$ & $-0.001 * * *$ & $-0.005 * * *$ & $-0.001 * * *$ \\
\hline & $(0.000)$ & $(0.000)$ & $(0.000)$ & (0.000) \\
\hline \multirow[t]{2}{*}{$\mathrm{GPM}_{\mathrm{t}-3}$} & $-0.001 * * *$ & $-0.001 * * *$ & $0.001 * * *$ & $-0.001 * * *$ \\
\hline & $(0.000)$ & $(0.000)$ & $(0.000)$ & $(0.000)$ \\
\hline \multirow[t]{2}{*}{ INDRETURN $_{\mathrm{t}}$} & & $0.000 * *$ & $0.000 * * *$ & $0.000 * * *$ \\
\hline & & $(0.000)$ & $(0.000)$ & $(0.000)$ \\
\hline \multirow[t]{2}{*}{$\mathrm{LNBSD}_{\mathrm{t}}$} & & $0.045 * * *$ & 0.013 & $0.024 *$ \\
\hline & & $(0.010)$ & $(0.011)$ & $(0.013)$ \\
\hline \multirow[t]{2}{*}{ LNEXPORT $_{t}$} & & $0.044 * * *$ & $0.039 * * *$ & -0.001 \\
\hline & & $(0.014)$ & $(0.015)$ & $(0.020)$ \\
\hline \multirow[t]{2}{*}{$\Delta \mathrm{GDP}_{\mathrm{t}}$} & & $0.002 * *$ & $0.005 * * *$ & 0.001 \\
\hline & & $(0.001)$ & $(0.001)$ & $(0.001)$ \\
\hline Firm fixed effects & Yes & Yes & No & Yes \\
\hline Period fixed effects & Yes & Yes & Yes & Yes \\
\hline Country dummies & No & No & Yes & No \\
\hline Country dummies $\times$ YEAR & No & No & No & Yes \\
\hline Adjusted $R^{2}$ & 0.517 & 0.517 & 0.349 & 0.518 \\
\hline$F$-statistic & $11.075 * * *$ & $11.083 * * *$ & $1,062.910 * * *$ & $11.091 * * *$ \\
\hline Firms included & 8,593 & 8,593 & 8,593 & 8,593 \\
\hline Observations & 81,120 & 81,120 & 81,120 & 81,120 \\
\hline
\end{tabular}


Table 6. The effect of debt maturity on future firm operating performance volatility and future firm value volatility.

This table presents the results of panel OLS regressions of future firm operating performance volatility and future firm value volatility on debt maturity for a sample of non-financial firms. Future firm operating performance volatility (SDROA) is measured as the three-year moving standard deviation of ROA (in columns (1)--(3)). Future firm value volatility (SRTBQ) is measured as the three-year rolling standard deviation of Tobin's Q (in columns (4)--(6)). All firm-level explanatory variables are three-period lagged. INDRETURN denotes the industry-level stock return (in \%), measured as the first difference in the natural logarithm of the industry price index. $\Delta$ GDP denotes the GDP growth rate (in $\%$ ); LNBSD is the natural logarithm of the percentage share of domestic credit to private sector by banks to GDP. LNEXPORT is the natural logarithm of the percentage share of export to GDP. All other variables are defined as in Table 1. Standard errors, which are robust to heteroskedasticity and serial correlation, are clustered at the firm level. We report standard errors in parentheses. Symbols $* * *, * *$, and $*$ denote significance at the $1 \%, 5 \%$ and $10 \%$ levels, respectively.

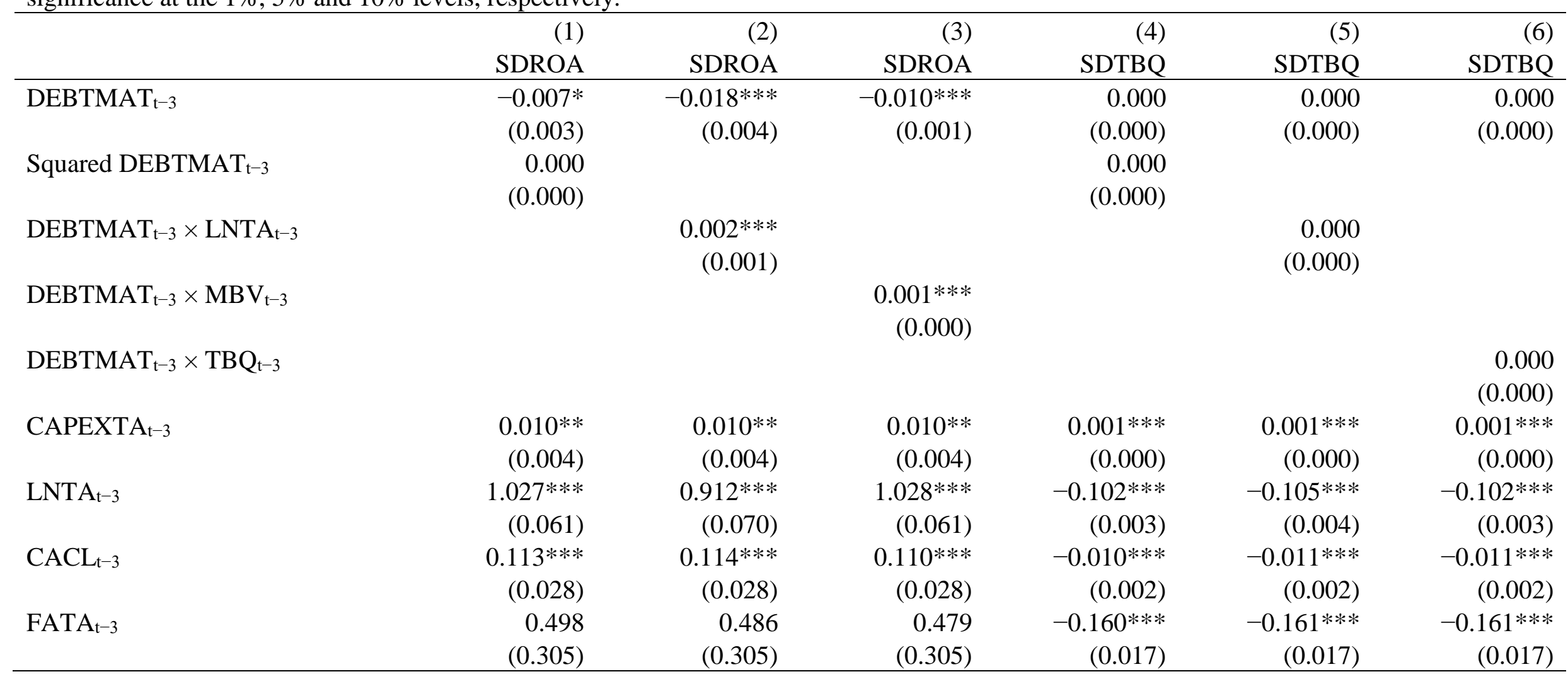




\begin{tabular}{|c|c|c|c|c|c|c|}
\hline $\mathrm{LEV}_{\mathrm{t}-3}$ & $\begin{array}{r}0.007 * * * \\
(0.002)\end{array}$ & $\begin{array}{r}0.007 * * * \\
(0.002)\end{array}$ & $\begin{array}{r}0.007 * * * \\
(0.002)\end{array}$ & $\begin{array}{r}0.000 * * * \\
(0.000)\end{array}$ & $\begin{array}{r}0.000 * * * \\
(0.000)\end{array}$ & $\begin{array}{r}0.000^{* * *} \\
(0.000)\end{array}$ \\
\hline $\mathrm{MBV}_{\mathrm{t}-3}$ & $\begin{array}{r}0.005 \\
(0.011)\end{array}$ & $\begin{array}{r}0.005 \\
(0.011)\end{array}$ & $\begin{array}{r}-0.060^{* * *} \\
(0.020)\end{array}$ & & & \\
\hline $\mathrm{ROA}_{\mathrm{t}-3}$ & $\begin{array}{r}-0.026^{* * *} \\
(0.002)\end{array}$ & $\begin{array}{r}-0.026^{* * *} \\
(0.002)\end{array}$ & $\begin{array}{r}-0.026 * * * \\
(0.002)\end{array}$ & $\begin{array}{r}-0.001 * * * \\
(0.000)\end{array}$ & $\begin{array}{r}-0.001 * * * \\
(0.000)\end{array}$ & $\begin{array}{r}-0.001 * * * \\
(0.000)\end{array}$ \\
\hline INDRETURN $_{\mathrm{t}}$ & $\begin{array}{r}-0.003 * * * \\
(0.001)\end{array}$ & $\begin{array}{r}-0.003 * * * \\
(0.001)\end{array}$ & $\begin{array}{r}-0.003 * * * \\
(0.001)\end{array}$ & $\begin{array}{r}0.000 * * \\
(0.000)\end{array}$ & $\begin{array}{r}0.000 * * * \\
(0.000)\end{array}$ & $\begin{array}{r}0.000 * * \\
(0.000)\end{array}$ \\
\hline LNBSD $_{t}$ & $\begin{array}{r}-1.932 * * * \\
(0.180)\end{array}$ & $\begin{array}{r}-1.949 * * * \\
(0.180)\end{array}$ & $\begin{array}{r}-1.925 * * * \\
(0.180)\end{array}$ & $\begin{array}{r}0.045^{* * *} * \\
(0.010)\end{array}$ & $\begin{array}{r}0.045^{* * *} * \\
(0.010)\end{array}$ & $\begin{array}{r}0.045^{* * *} \\
(0.010)\end{array}$ \\
\hline LNEXPORT $_{t}$ & $\begin{array}{r}0.746^{* * * *} \\
(0.250)\end{array}$ & $\begin{array}{r}0.749 * * * \\
(0.250)\end{array}$ & $\begin{array}{r}0.741^{* * *} * \\
(0.250)\end{array}$ & $\begin{array}{r}0.045^{* * *} * \\
(0.014)\end{array}$ & $\begin{array}{r}0.044 * * * \\
(0.014)\end{array}$ & $\begin{array}{r}0.044 * * * \\
(0.014)\end{array}$ \\
\hline $\begin{array}{l}\text { Period fixed effects } \\
\text { Adjusted } R^{2}\end{array}$ & $\begin{array}{r}\text { Yes } \\
0.464\end{array}$ & $\begin{array}{r}\text { Yes } \\
0.464\end{array}$ & $\begin{array}{r}\text { Yes } \\
0.464\end{array}$ & $\begin{array}{r}\text { Yes } \\
0.517\end{array}$ & $\begin{array}{r}\text { Yes } \\
0.517\end{array}$ & $\begin{array}{r}\text { Yes } \\
0.517\end{array}$ \\
\hline$F$-statistic & $9.153 * * *$ & $9.157 * * *$ & $9.158 * * *$ & $11.082 * * *$ & $11.082 * * *$ & $11.082 * * *$ \\
\hline Firms included & 8,593 & 8,593 & 8,593 & 8,593 & 8,593 & 8,593 \\
\hline Observations & 81,120 & 81,120 & 81,120 & 81,120 & 81,120 & 81,120 \\
\hline
\end{tabular}


Table 7. The effect of debt maturity on future firm operating performance volatility and future firm value volatility: The moderating effect of economic development.

This table presents the results of panel OLS regressions of future firm operating performance volatility and future firm value volatility on debt maturity for a sample of non-financial firms. Future firm operating performance volatility (SDROA) is measured as the three-year moving standard deviation of ROA (in columns (1)). Future firm value volatility (SDTBQ) is measured as the three-year rolling standard deviation of Tobin's Q (in columns (2)). A developed country (DEV) variable takes a value of one for firms listed in a developed country, and zero otherwise. All firm-level explanatory variables are three-period lagged. INDRETURN denotes the industry-level stock return (in \%), measured as the first difference in the natural logarithm of the industry price index. $\triangle$ GDP denotes the GDP growth rate (in \%); LNBSD is the natural logarithm of the percentage share of domestic credit to private sector by banks to GDP. LNEXPORT is the natural logarithm of the percentage share of export to GDP. All other variables are defined as in Table 1. Standard errors, which are robust to heteroskedasticity and serial correlation, are clustered at the firm level. We report standard errors in parentheses. Symbols $* * *, * *$, and $*$ denote significance at the $1 \%, 5 \%$ and $10 \%$ levels, respectively.

\begin{tabular}{|c|c|c|}
\hline & $\begin{array}{r}(1) \\
\text { SDROA }\end{array}$ & $\begin{array}{r}(2) \\
\text { SDTBQ }\end{array}$ \\
\hline DEBTMAT $_{t-3}$ & $\begin{array}{r}-0.012 * * * \\
(0.003)\end{array}$ & $\begin{array}{r}0.000 \\
(0.000)\end{array}$ \\
\hline DEBTMAT $_{\mathrm{t}-3} \times \mathrm{DEV}_{\mathrm{t}-3}$ & $\begin{array}{r}0.005^{*} \\
(0.003)\end{array}$ & $\begin{array}{r}0.000 \\
(0.000)\end{array}$ \\
\hline CAPEXTA $_{t-3}$ & $\begin{array}{r}0.010 * * \\
(0.004)\end{array}$ & $\begin{array}{r}0.001 * * * \\
(0.000)\end{array}$ \\
\hline $\mathrm{LNTA}_{\mathrm{t}-3}$ & $\begin{array}{r}1.026 * * * \\
(0.061)\end{array}$ & $\begin{array}{r}-0.102 * * * \\
(0.003)\end{array}$ \\
\hline $\mathrm{CACL}_{t-3}$ & $\begin{array}{r}0.114 * * * \\
(0.028)\end{array}$ & $\begin{array}{r}-0.011 * * * \\
(0.002)\end{array}$ \\
\hline FATA $_{t-3}$ & $\begin{array}{c}0.507^{*} \\
(0.305)\end{array}$ & $\begin{array}{r}-0.161 * * * \\
(0.017)\end{array}$ \\
\hline $\mathrm{LEV}_{\mathrm{t}-3}$ & $\begin{array}{r}0.007 * * * \\
(0.002)\end{array}$ & $\begin{array}{r}0.000 * * * \\
(0.000)\end{array}$ \\
\hline $\mathrm{MBV}_{\mathrm{t}-3}$ & $\begin{array}{r}0.005 \\
(0.011)\end{array}$ & \\
\hline $\mathrm{TBQ}_{\mathrm{t}-3}$ & & $\begin{array}{r}0.087 * * * \\
(0.002)\end{array}$ \\
\hline $\mathrm{ROA}_{\mathrm{t}-3}$ & $\begin{array}{r}-0.026 * * * \\
(0.002)\end{array}$ & $\begin{array}{r}-0.001 * * * \\
(0.000)\end{array}$ \\
\hline $\mathrm{GPM}_{\mathrm{t}-3}$ & $\begin{array}{r}-0.021 * * * \\
(0.003)\end{array}$ & $\begin{array}{r}-0.001 * * * \\
(0.000)\end{array}$ \\
\hline INDRETURN $_{\mathrm{t}}$ & $\begin{array}{r}-0.003 * * * \\
(0.001)\end{array}$ & $\begin{array}{r}0.000^{* *} \\
(0.000)\end{array}$ \\
\hline LNBSD $_{t}$ & $\begin{array}{r}-1.942 * * * \\
(0.180)\end{array}$ & $\begin{array}{r}0.045^{* * * *} \\
(0.010)\end{array}$ \\
\hline $\mathrm{LNEXPORT}_{\mathrm{t}}$ & $\begin{array}{r}0.736 * * * \\
(0.250)\end{array}$ & $\begin{array}{r}0.044 * * * \\
(0.014)\end{array}$ \\
\hline$\Delta \mathrm{GDP}_{\mathrm{t}}$ & $\begin{array}{r}-0.066^{* * * *} \\
(0.014)\end{array}$ & $\begin{array}{r}0.002 * * \\
(0.001)\end{array}$ \\
\hline Firm fixed effects & Yes & Yes \\
\hline
\end{tabular}


Period fixed effects

Adjusted $R^{2}$

$F$-statistic

Firms included

Observations

\begin{tabular}{rr} 
Yes & Yes \\
0.464 & 0.517 \\
$.154 * * *$ & $11.082 * * *$ \\
8,593 & 8,593 \\
81,120 & 81,120 \\
\hline
\end{tabular}


Table 8. The effect of debt maturity on future firm operating performance volatility and future firm value volatility: Different sample periods.

This table presents the results of panel OLS regressions of future firm operating performance volatility and future firm value volatility on debt maturity for a sample of non-financial firms. Firm operating performance volatility is measured as the three-year moving standard deviation of ROA (in columns (1)--(3)), whereas firm value volatility is measured as the three-year rolling standard deviation of Tobin's Q (in columns (4)-(6)). A developed country (DEV) variable takes a value of one for firms listed in a developed country and zero otherwise. All firm-level explanatory variables are three-period lagged. INDRETURN denotes the industry-level stock return (in \%), measured as the first difference in the natural logarithm of the industry price index. $\triangle$ GDP denotes the GDP growth rate (in \%); LNBSD is the natural logarithm of the percentage share of domestic credit to private sector by banks to GDP. LNEXPORT is the natural logarithm of the percentage share of export to GDP. All other variables are defined as in Table 1 . Standard errors, which are robust to heteroskedasticity and serial correlation, are clustered at the firm level. We report standard errors in parentheses. Symbols ***,**, and * denote significance at the 1\%, 5\% and $10 \%$ levels, respectively.

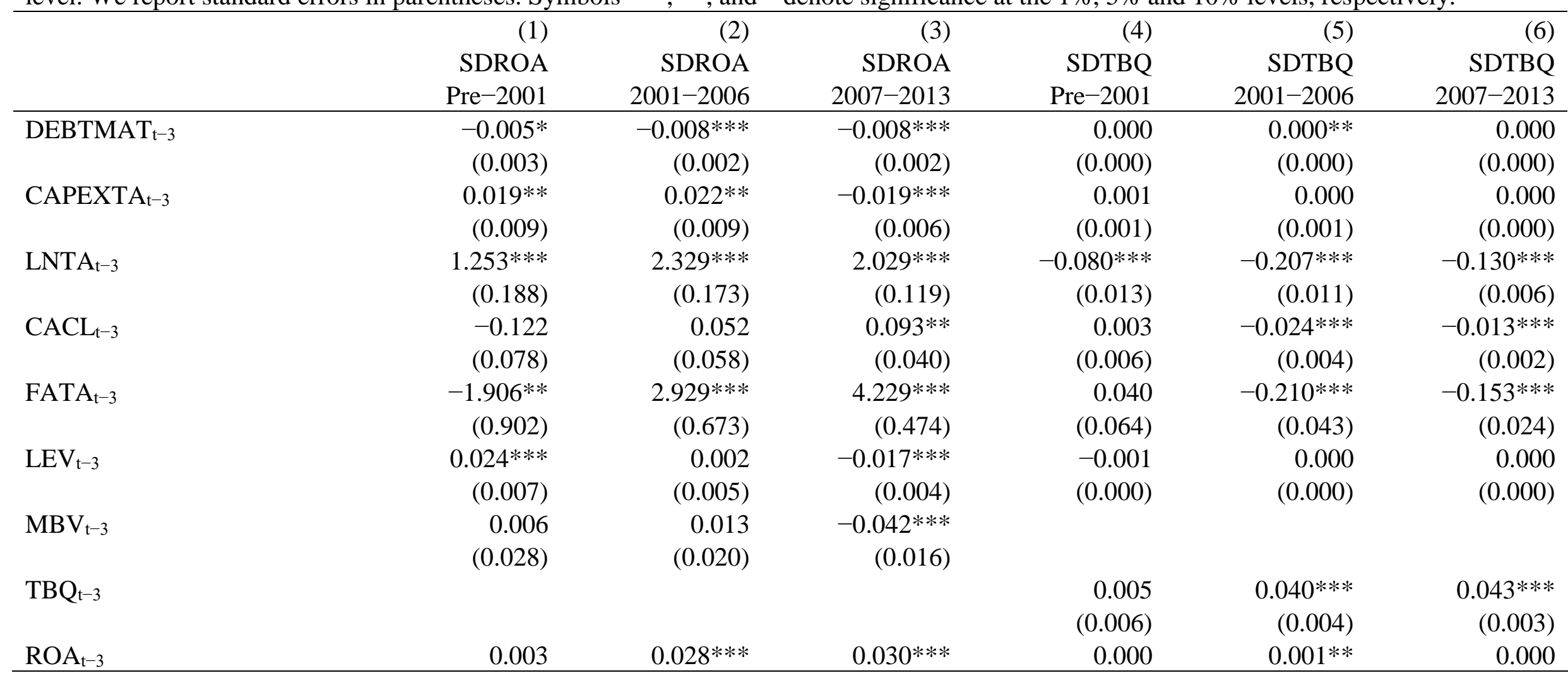




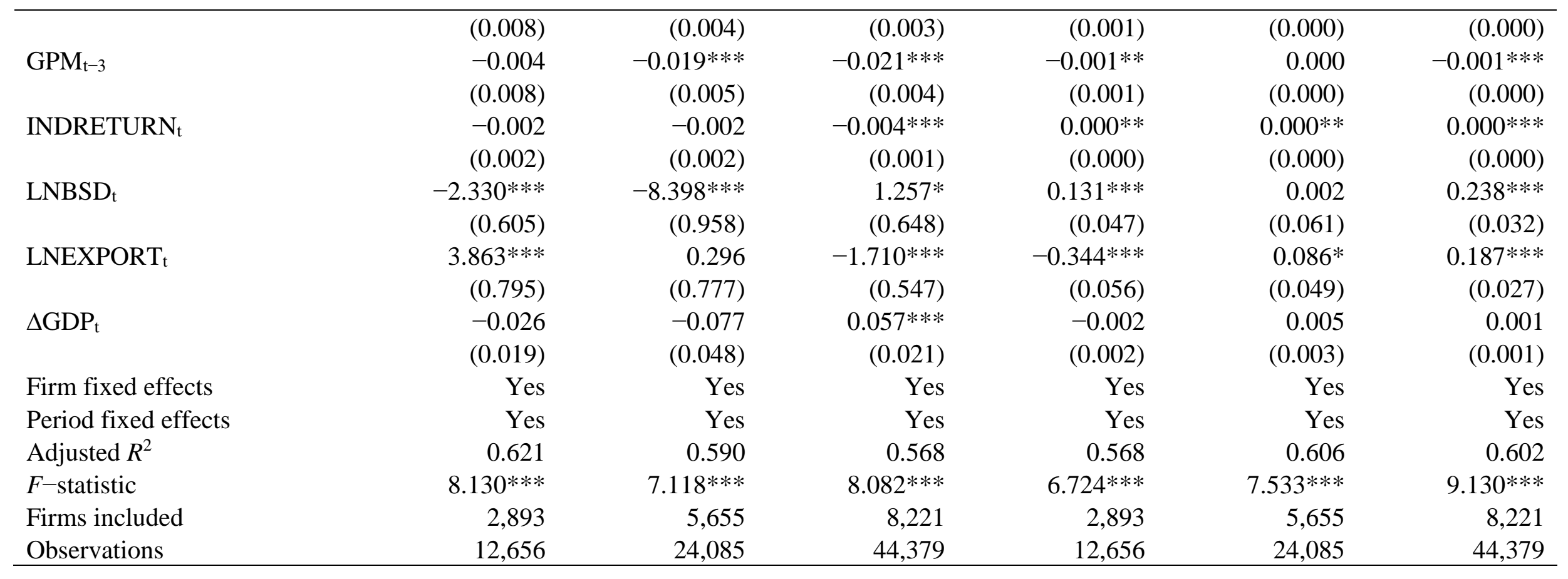


Table 9. Robustness checks: Alternative measures of future firm operating performance volatility and future firm value volatility.

This table presents the results of panel OLS regressions of future firm operating performance volatility and future firm value volatility on debt maturity for a sample of non-financial firms. In columns (1)--(3), firm operating performance volatility (SDROA2) is measured as the five-year moving standard deviation of ROA. In columns (4)--(6), firm value volatility (SDTBQ2) is measured as the five-year rolling standard deviation of Tobin's Q. A developed country (DEV) variable takes a value of one for firms listed in a developed country and zero otherwise. All firm-level explanatory variables are five-period lagged. INDRETURN denotes the industry-level stock return (in \%), measured as the first difference in the natural logarithm of the industry price index. $\triangle$ GDP denotes the GDP growth rate (in \%); LNBSD is the natural logarithm of the percentage share of domestic credit to private sector by banks to GDP. LNEXPORT is the natural logarithm of the percentage share of export to GDP. All other variables are defined as in Table 1. Standard errors, which are robust to heteroskedasticity and serial correlation, are clustered at the firm level. We report standard errors in parentheses. Symbols ***,**, and * denote significance at the 1\%, 5\% and $10 \%$ levels, respectively.

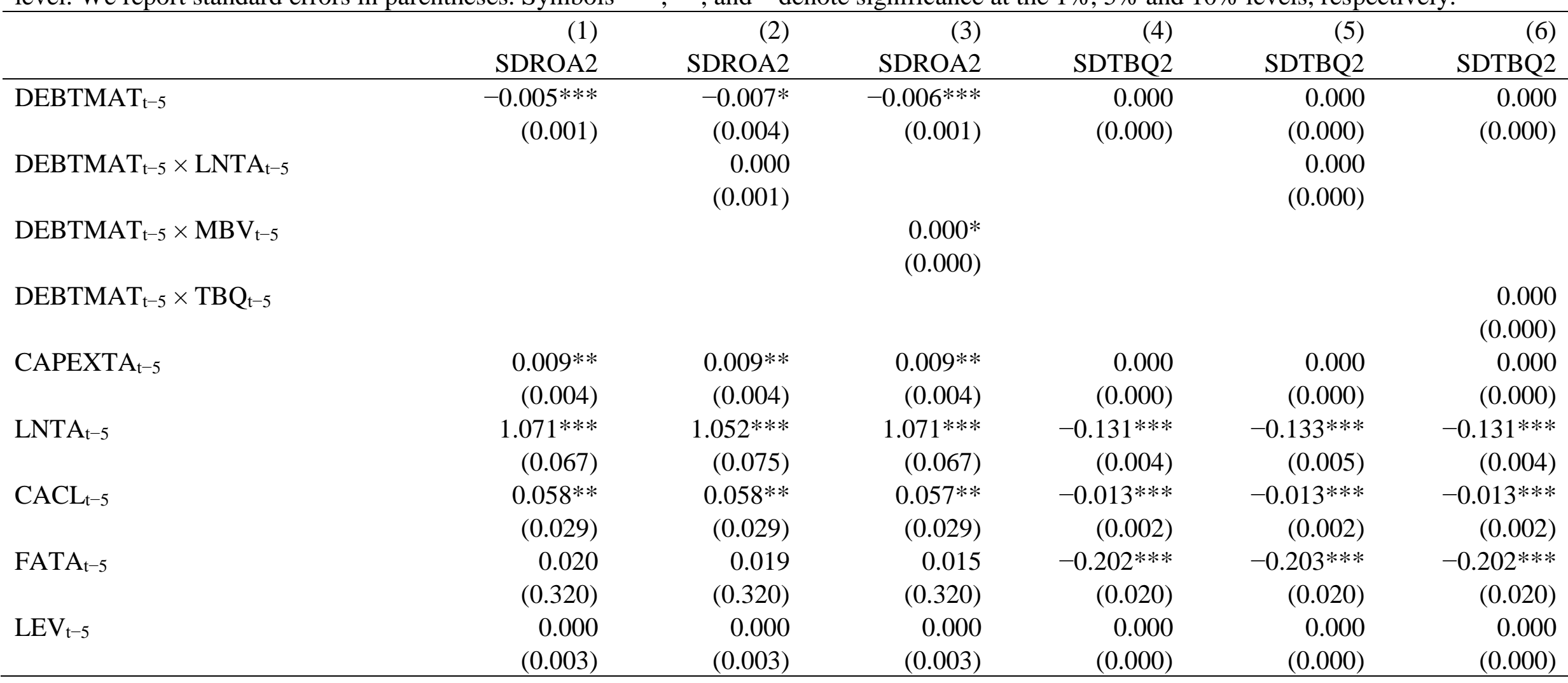




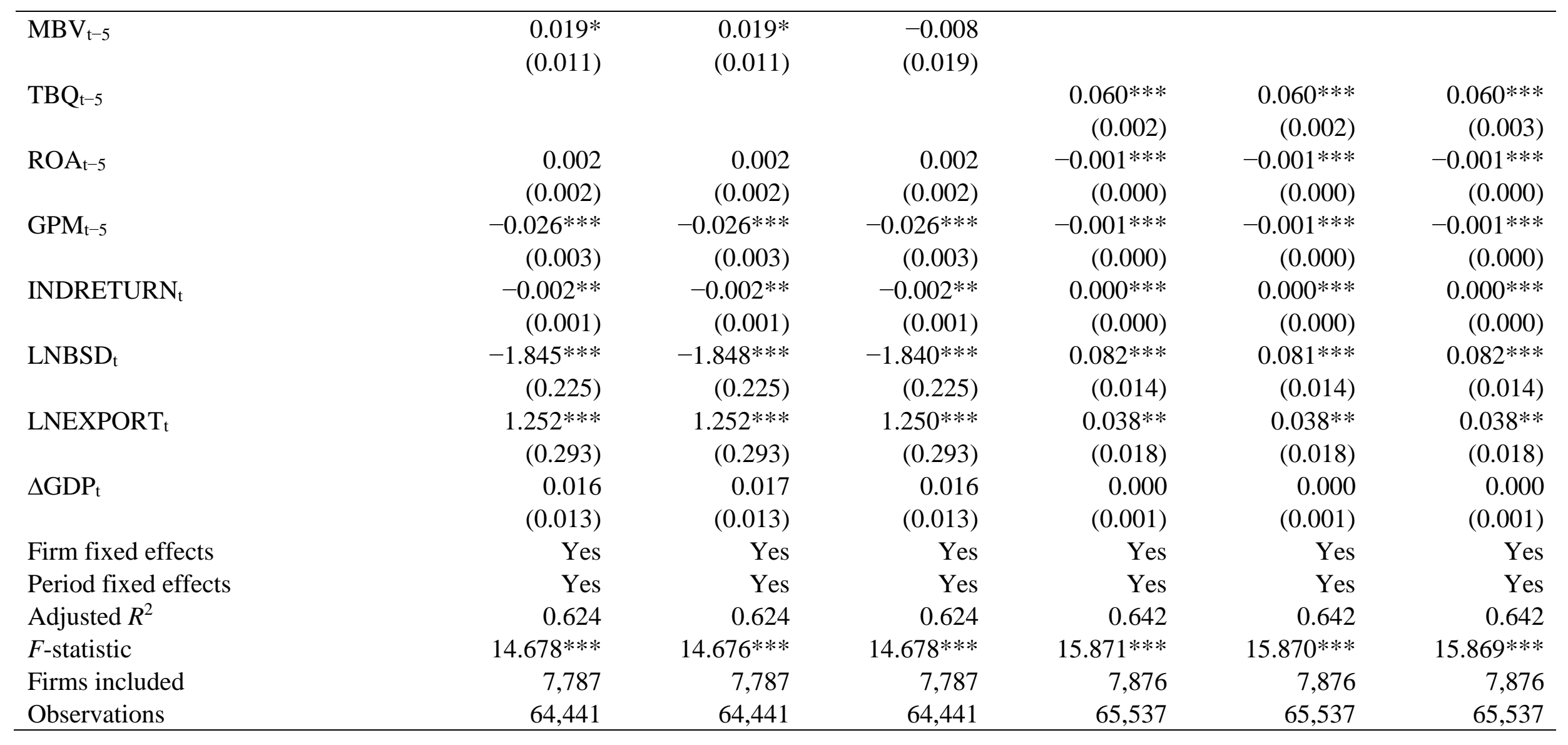


Table 10. Robustness checks: Two-stage least squares regressions of future firm operating performance volatility and future firm value volatility. This table presents the second-stage results of two-stage least squares (2SLS) regressions. In the first-stage regression, debt maturity is the dependent variable; the one-year lagged country-year average debt maturity and a set of lagged firm-level variables, industry stock returns, and country-level variables are the independent variables. The predicted value of debt maturity (PDEBTMAT) from the first-stage regression is used as an explanatory variable in the second-stage regression. Future firm operating performance volatility (SDROA), measured as the three-year moving standard deviation of ROA (in columns (1)--(4)), and (2) future firm value volatility (SDTBQ), measured as the three-year rolling standard deviation of Tobin's Q (in columns (5)--(8)), are the dependent variable in the second-stage regression. All firm-level explanatory variables in the second-stage regressions are three-period lagged. INDRETURN denotes the industry-level stock return (in \%), measured as the first difference in the natural logarithm of the industry price index. $\triangle$ GDP denotes the GDP growth rate (in \%); LNBSD is the natural logarithm of the percentage share of domestic credit to private sector by banks to GDP. LNEXPORT is the natural logarithm of the percentage share of export to GDP. All other variables are defined as in Table 1. Standard errors, which are robust to heteroskedasticity and serial correlation, are clustered at the firm level. We report standard errors in parentheses. Symbols ***, **, and * denote significance at the $1 \%, 5 \%$ and $10 \%$ levels, respectively.

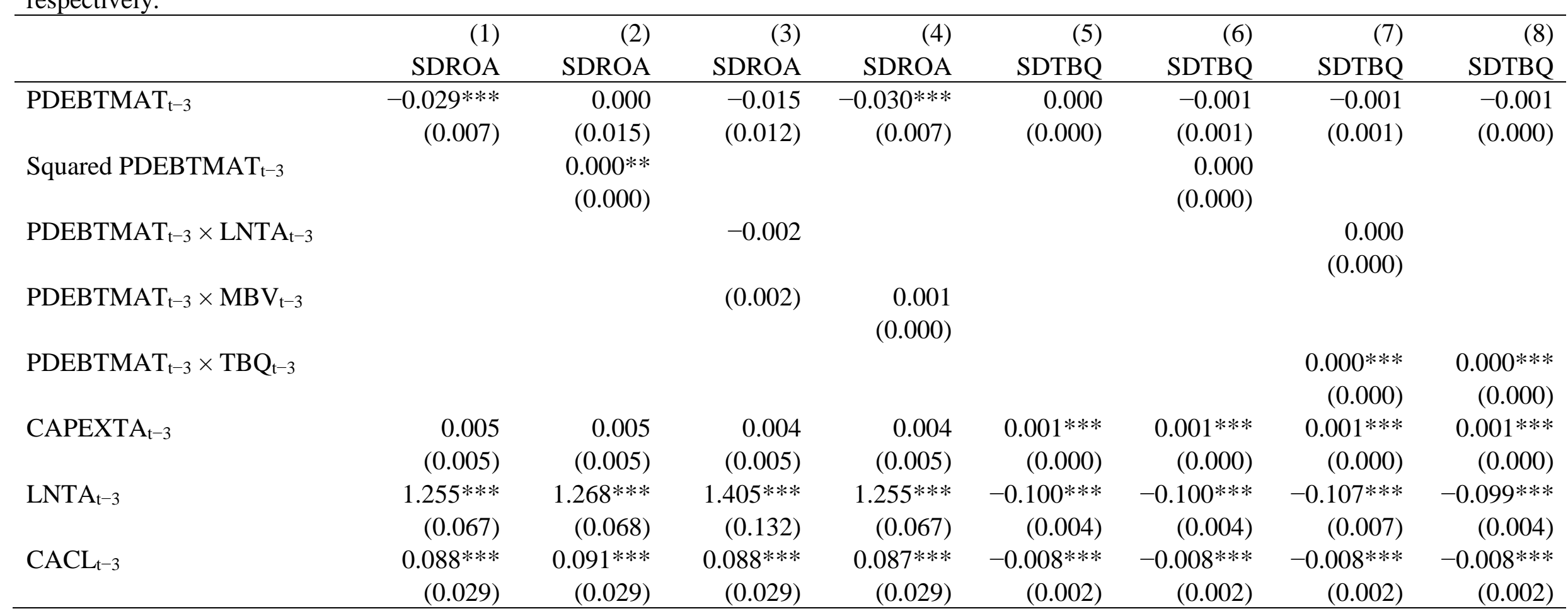




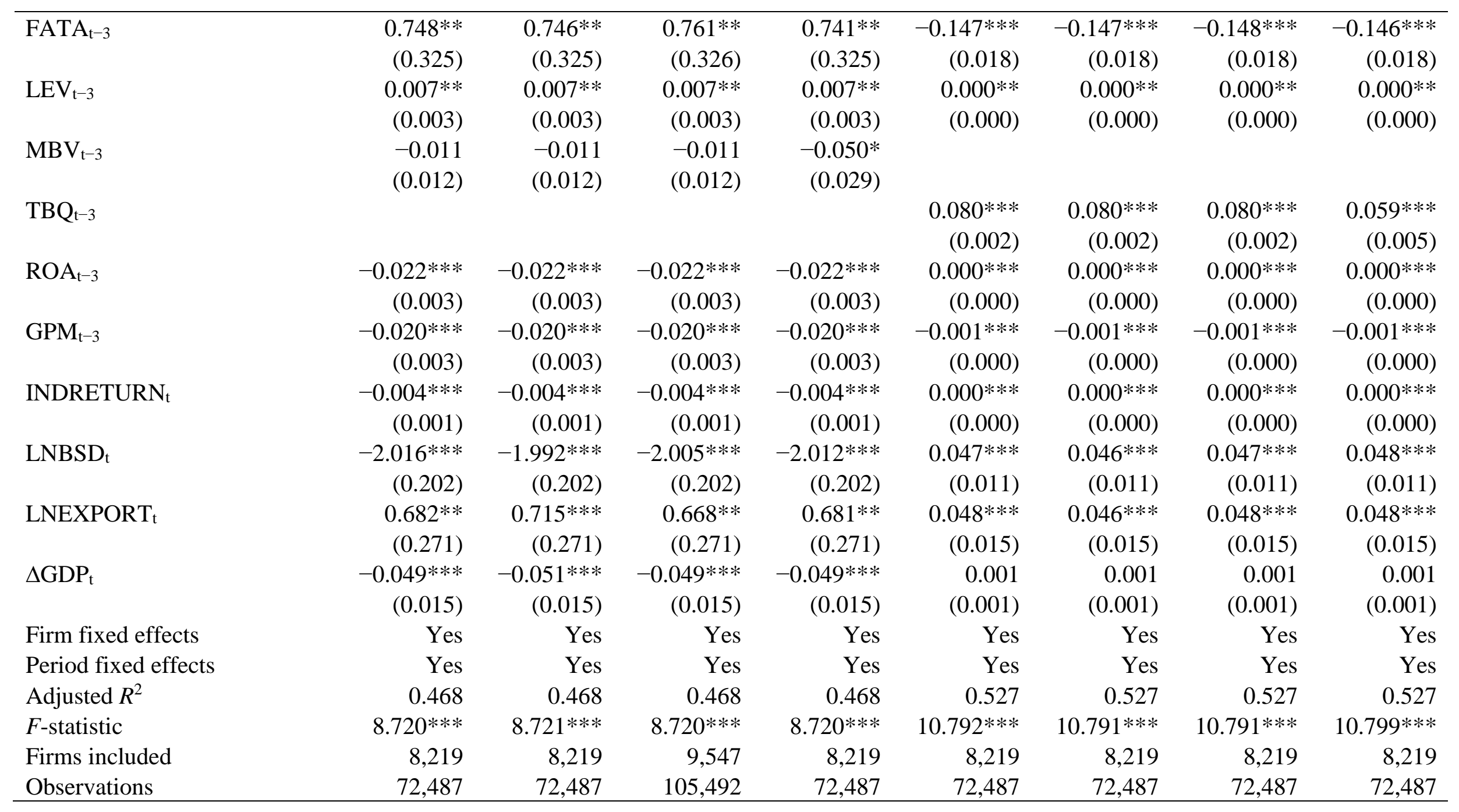


Figure 1. Debt maturity, firm operating performance volatility and firm value volatility.

This figure presents the average values for debt maturity (DEBTMAT), firm operating performance volatility (SDROA), and firm value volatility (SDTBQ) based on a sample of 95,240 firm-year observations. For ease of presentation, we divide the values for DEBTMAT and SDROA by 100 .

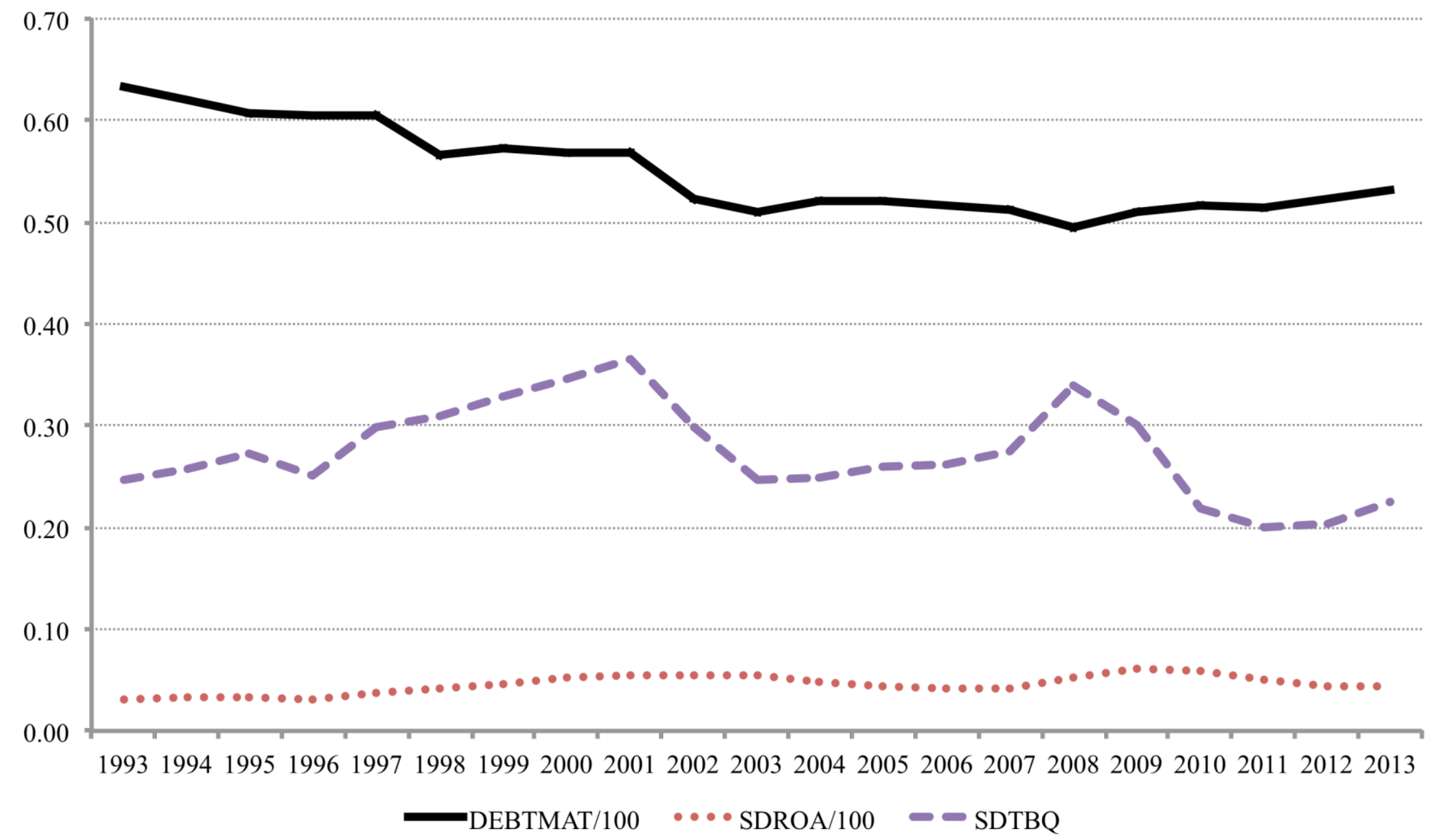

